\title{
The IPCC: A Primer for Archaeologists
}

\author{
Timothy A. Kohler (iD) and Marcy Rockman
}

\begin{abstract}
The Intergovernmental Panel on Climate Change (IPCC) was founded in 1988 to provide governments with policy-relevant assessments of climate science as well as options for adaptation and mitigation. It is now recognized as providing the leading global compilation of climate science, adaptation, and mitigation research. The volunteer scientists who write these reports have carried out five complete assessment cycles, with the sixth cycle to be completed in 2022. Here, we review how information from and about archaeology and other forms of cultural heritage has been incorporated into these reports to date. Although this review shows that archaeology has not been wholly absent from work of the IPCC, we suggest that archaeology has more to offer the IPCC and global climate response. We propose five ways to more fully engage both archaeologists and knowledge from and about the human past in IPCC assessments and reports.
\end{abstract}

Keywords: IPCC, archaeology, heritage, climate change, paleoclimate, attribution, adaptation, preservation

El Panel Intergubernamental del Cambio Climático (IPCC por sus siglas en inglés) fue fundado en 1988 con el objetivo de proporcionar tanto evaluaciones de las ciencias climáticas relevantes a las políticas gubernamentales, como opciones para adaptación y mitigación a los gobiernos a nivel internacional. Al presente, este cuerpo intergubernamental es reconocido como la fuente principal de compilaciones sobre las investigaciones desde las ciencias climáticas, de adaptación y de mitigación. Los científicos que voluntariamente escriben los reportes para el IPCC han completado cinco ciclos de evaluaciones, y se encuentran trabajando en el sexto ciclo que terminarán en 2022. En este artículo, los autores revisamos cómo la información de y sobre la arqueología y otras formas de patrimonio cultural han sido incorporadas en estos reportes hasta el momento. Aún cuando esta revisión demuestra que la arqueología no ha estado totalmente ausente del trabajo del IPCC, los autores sugerimos que la arqueología tiene mucho más que ofrecer, tanto al IPCC como a la respuesta climática global. A estos efectos, proponemos cinco maneras en que tanto los arqueólogos como el conocimiento del pasado y sobre él pueden ser incorporados más plenamente en las evaluaciones y reportes del IPCC.

Palabras clave: IPCC, arqueología, patrimonio, cambio climático, paleoclima, atribución, adaptación, preservación

A lthough many archaeologists recognize the modern challenges of climate change, many are not familiar with the abbreviation "IPCC." Furthermore, even those connecting these initials to the Intergovernmental Panel on Climate Change have relatively little familiarity with what it is and how it works. Here, we aim to demystify this organization, which requires us as historical scholars to present an origin story and a brief account of its subsequent development and current structure. Our main interest, however, is to understand why the findings of our discipline have been so little employed by IPCC scientists and to provide

Timothy A. Kohler (tako@ wsu.edu, corresponding author) — Department of Anthropology, Washington State University, Pullman, WA 99164-4910, USA; Santa Fe Institute, 1399 Hyde Park Road, Santa Fe, NM 87501, USA

Marcy Rockman $\mathbf{~ I n t e r n a t i o n a l ~ C o u n c i l ~ o n ~ M o n u m e n t s ~ a n d ~ S i t e s ~ ( I C O M O S ) ~ a n d ~ C o - E q u a l , ~} 1201$ Connecticut Avenue NW, Washington, DC 20036, USA

American Antiquity 85(4), 2020, pp. 627-651

Copyright $@$ The Author(s), 2020. Published by Cambridge University Press on behalf of the Society for American Archaeology. This is an Open Access article, distributed under the terms of the Creative Commons Attribution licence (http://creativecommons.org/licenses/by/4.0/), which permits unrestricted re-use, distribution, and reproduction in any medium, provided the original work is properly cited.

doi:10.1017/aaq.2020.68 
some suggestions for making knowledge and practice from and about the human past more relevant to the IPCC and global climate response.

\section{Purpose and Structure of the IPCC}

The IPCC was created by the United Nations Environment Programme (UNEP) and the World Meteorological Organization (WMO) in 1988, and it was officially adopted by the UN General Assembly in December of that year (Resolution 43/53). This resolution directed UNEP and WMO to work through the IPCC to "initiate action leading, as soon as possible, to a comprehensive review and recommendations" with respect to the state of knowledge on (1) the climate and climate change; (2) studies on the social and economic impacts of these changes; and (3) strategies to "delay, limit, or mitigate the impacts of adverse climate change" (United Nations General Assembly 1988:134). The resolution also asked the new body to identify and possibly advise on strengthening existing international legal instruments bearing on climate, as well as consider what elements would need to be included in a future international convention on climate.

Requests 1-3 led, respectively, to the three present Working Groups (WG) of the IPCC. WGI deals with the physical science of climate change in the past, present, and future. Scientists contributing to WGI reports tend to include climatologists, meteorologists, physical geographers, atmospheric physicists, hydrologists, and others. Scientists within WGII include biologists (botanists, zoologists, marine biologists, and especially ecologists), geoscientists, and diverse social scientists such as human geographers, urban scientists, agricultural scientists, economists, and sociologists. Their domain includes both the ecological and the social effects of climate impact drivers (e.g., rising sea levels). Authors of WGIII reports come from a variety of disciplines, including international law, political science, engineering, and systems science. In the jargon of the IPCC, mitigation - the domain of WGIII-describes actions that prevent greenhouse gases from entering the atmosphere in the first place or removes them once they are there. The IPCC seems to attract researchers who like working across disciplines, and quite a few have made contributions to more than one WG.

Beginning in 1990, the IPCC has delivered five major Assessment Reports (ARs) and a number of more specialized reports (Table 1). These reports are intended to "provide a scientific basis for governments at all levels to develop climate-related policies" (IPCC 2020a:1) and to be useful for negotiations at the UN Climate Conference-known as the United Nations Framework Convention on Climate Change (UNFCCC). These assessments are designed to be "policy relevant but not policy prescriptive" (IPCC 2020a:1). Although primarily intended for use by its 125 member governments, IPCC reports are widely regarded as the most comprehensive compendium and assessment of climate-related science available, and they often become widely cited in both the primary research literature and popular media. The Sixth Assessment Report (AR6) is currently underway. Its several volumes will be published in 2021 and 2022.

The IPCC maintains a Bureau of 34 members who are elected by the member governments of the IPCC Panel for the duration of an assessment cycle. Neither the Bureau members, nor the authors or reviewers of the reports, are paid by the IPCC. The Bureau coordinates many aspects of the production of the reports via the staff of a Technical Support Unit (TSU) attached to each WG and the secretariat of the IPCC, which is headquartered in Geneva. Four main categories of authors are recognized: Coordinating Lead Authors (CLAs), Lead Authors (LAs), and Review Editors (REs). Authors are selected following nominations from governments and IPCC observer organizations, including a number of UN bodies and other international organizations, intergovernmental organizations such as the European Union, and 100 nongovernmental organizations (complete current lists at IPCC 2018). IPCC Bureau members may also make nominations after the outline of a report has been agreed upon (IPCC 2020b). These authors may be assisted by Contributing Authors (CAs), who provide expertise on particular topics at the request of the CLAs or the LAs. Authors of each WG are convened separately several times during each assessment cycle to work face-to-face 
Table 1. Past Major IPCC Reports and Their Usage of Archaeological/Heritage Information. ${ }^{\text {a }}$

\begin{tabular}{|c|c|c|c|}
\hline Date & Acronym & Full Title & Uses Heritage Data? \\
\hline \multirow[t]{3}{*}{1990} & FAR WGI (or AR1 WGI) & Climate Change: The IPCC Assessment & No \\
\hline & $\begin{array}{l}\text { FAR WGII } \\
\quad \text { (or AR1 WGII) }\end{array}$ & Climate Change: The IPCC Impacts Assessment & Yes \\
\hline & $\begin{array}{l}\text { FAR WGIII } \\
\text { (or AR1 WGIII) }\end{array}$ & Climate Change: The IPCC Response Strategies & Yes \\
\hline 1992 & $\begin{array}{l}\text { FAR SPM } \\
\text { (or AR1 Synthesis) }\end{array}$ & $\begin{array}{l}\text { Climate Change: The IPCC } 1990 \text { and } 1992 \text { Assessments IPCC First Assessment Report Overview and } \\
\text { Policymaker Summaries and } 1992 \text { IPCC Supplement }\end{array}$ & Yes \\
\hline 1992 & WGI 1992 Supplement & Climate Change 1992: The Supplementary Report to the IPCC Scientific Assessment & No \\
\hline 1992 & WGII 1992 Supplement & Climate Change 1992: The Supplementary Report to the IPCC Impacts Assessment & Yes \\
\hline 1994 & IPCC Technical Guidelines 1994 & IPCC Technical Guidelines for Assessing Climate Change Impacts and Adaptations & No \\
\hline 1995 & SAR WGI (or AR2 WGI) & Climate Change 1995: The Science of Climate Change & Yes \\
\hline 1995 & $\begin{array}{l}\text { SAR WGII } \\
\quad \text { (or AR2 WGII) }\end{array}$ & $\begin{array}{l}\text { Climate Change 1995: Impacts, Adaptations, and Mitigation of Climate Change: Scientific-Technical } \\
\text { Analyses }\end{array}$ & Yes \\
\hline \multirow[t]{3}{*}{2001} & TAR WGI & Climate Change 2001: The Scientific Basis & Yes \\
\hline & TAR WGII & Climate Change 2001: Impacts, Adaptation, and Vulnerability & Yes \\
\hline & SYR TAR & Climate Change 2001: Synthesis Report & Yes \\
\hline \multirow[t]{3}{*}{2007} & AR4 WG1 & Climate Change 2007: The Physical Science Basis & Yes \\
\hline & AR4 WGII & Climate Change 2007: Impacts, Adaptation, and Vulnerability & Yes \\
\hline & AR4 SYR & Climate Change 2007: Synthesis Report & Indigenous only \\
\hline 2013 & AR5 WG1 & Climate Change 2013: The Physical Science Basis & Yes \\
\hline 2014 & AR5 WG2A & Climate Change 2014: Impacts, Adaptation, and Vulnerability. Part A: Global and Sectoral Aspects & Yes \\
\hline 2014 & AR5 WG2B & Climate Change 2014: Impacts, Adaptation, and Vulnerability Part B: Regional Aspects & Yes \\
\hline 2018 & SR15 SPM ${ }^{b}$ & Global Warming of $1.5^{\circ} \mathrm{C}$ & Indigenous only \\
\hline 2019 & $\begin{array}{l}\text { SRCCL } \\
\quad \text { (approved draft) }\end{array}$ & $\begin{array}{l}\text { IPCC Special Report on Climate Change, Desertification, Land Degradation, Sustainable Land } \\
\text { Management, Food Security, and Greenhouse Gas Fluxes in Terrestrial Ecosystems }\end{array}$ & Indigenous only \\
\hline 2019 (in press) & SROCC & The Ocean and Cryosphere in a Changing Climate & Yes \\
\hline
\end{tabular}

${ }^{a}$ The text provides illustrative examples of the nature of this information and how it has been employed in the IPCC reports. The listing of specialized reports is not comprehensive.

${ }^{\mathrm{b}}$ Summary for Policy Makers. 
on their reports, although a great deal of the writing takes place at their home institutions distributed all over the world.

Reports are reviewed in a three-stage process that involves both external experts and governments (IPCC 2013). The first two stages concentrate on scientific issues such as whether all important studies have been included and whether their findings have been weighted properly. Following appropriate revisions, these volumes are then combined into technical reports by the TSU, which become the basis for shorter documents (one for each WG) called the Summaries for Policymakers (SPMs). These are subject to a line-by-line review by government representatives, in which technical experts also participate. The original book-length reports on which the SPMs are based are not subject to this final review.

\section{Origins}

We identify two complementary sources of concerns leading the UN to establish the IPCC. On one hand, there is a long chain of increasingly ecocentric thought stretching back at least to George Perkins Marsh (1864) and continuing through Teddy Roosevelt and the conservation movement of the late nineteenth/early twentieth century-including Gifford Pinchot and John Muir, the latter of whom founded the Sierra Club in 1892 (De Steiguer 2006). The geopolitical concerns of two world wars slowed this movement, despite the continued presence of original thinkers such as Aldo Leopold (1949). But there was a strong resurgence in the 1960s.

First among many prominent contributors to this resurgence was Rachel Carson, whose blockbuster Silent Spring (1962) helped lead to the founding of the U.S. Environmental Protection Agency (EPA) in 1970. Silent Spring was soon followed by a number of influential works, including Scarcity and Growth: The Economics of Natural Resource Availability (Barnett and Morse 1963), The Quiet Crisis (1963) by the then secretary of the interior, Stewart L. Udall, and Roderick Nash's Wilderness and the American Mind (1967), among others. The mounting interest and widespread concern about environmental matters led to the first Earth Day celebration in 1970, which the senior author remembers as a highly significant public event. Perhaps $10 \%$ of the U.S. population "took to the streets, parks and auditoriums to demonstrate for a healthy, sustainable environment in massive coast-tocoast rallies" (EarthDay.org 2020). It may not be too far a stretch to infer that many of the young people coming into archaeology in the 1960 s and early 1970s, at least in the United States and Canada, were attracted to the field because of its involvement with ecology - particularly what Trigger called "open-system ecology" (1971)—and its interest in how societies adapt to their environments (Watson 2008).

Although the 1970s saw a general decrease in environmental fervor (De Steiguer 2006), a number of scientific concerns of the 1980s, including acid rain, global warming, depletion of the stratospheric ozone layer, and tropical deforestation achieved widespread public recognition. Scientific and public concern over global warming in particular were important to the formation of the IPCC.

And that leads to the second impetus for its formation: throughout the twentieth century, science on global warming was rapidly accumulating. Svante Arrhenius-the first Swedish Nobel laureate for his work on electrolytes-published a remarkable first draft of how this process works in "On the Influence of Carbonic Acid in the Air upon the Temperature of the Ground" (1896). In it, he consolidated work by earlier researchersincluding John Tyndall and Ernst Lecherdemonstrating that atmospheric concentrations of what he called carbonic acid $\left(\mathrm{CO}_{2}\right)$ and water vapor affect the earth's temperature, eventually deriving the expectation that, all else equal, "any doubling of the percentage of carbon dioxide in the air would raise the temperature of the earth's surface by $4^{\circ}[\mathrm{C}] "$ (1908:53). This equilibrium, or "effective" (if an equilibrium cannot be assessed) climate sensitivity, as it is now called, is (remarkably) still within the "medium confidence" range of $1.5^{\circ} \mathrm{C}-4.5^{\circ} \mathrm{C}$ used by the most recent assessment report (AR5; Stocker et al. 2013) and also within the range of the higher sensitivities (of about $\left.1.8^{\circ} \mathrm{C}-5.6^{\circ} \mathrm{C}\right)$ that the most current models suggest (Zelinka et al. 2020).

Indeed, the instrumented record of the global (land and ocean) mean surface temperature 


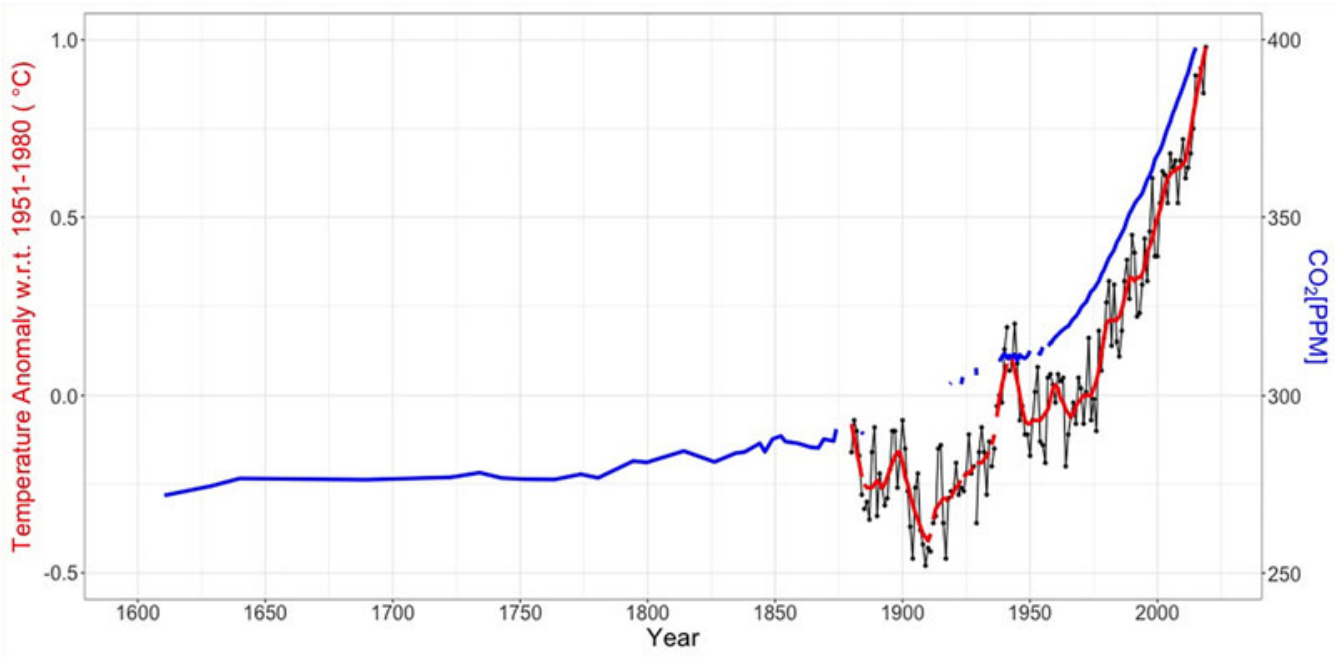

Figure 1. Global mean surface temperatures from 2020 NASA calculations (NASA GISS), overlaid on Keeling curve/ ice-core data measuring $\mathrm{CO}_{2}$.

(GMST) as compiled by NASA (GISTEMP Team 2020) is completely unambiguous on the recent global temperature increase (Figure 1). Other GMST estimates, produced by the National Oceanic and Atmospheric Administration (NOAA), the Berkeley Earth research group, the Met Office Hadley Centre (MOHC), and the Cowtan and Way analysis, are in essential agreement (NASA 2020). Perhaps surprisingly, given the critical nature of atmospheric $\mathrm{CO}_{2}$ (and other greenhouse gases such as methane), it was not until 1958 that the first systematic series of atmospheric $\mathrm{CO}_{2}$ measurements began, at the Mauna Loa Observatory of Hawaii under the direction of Charles David Keeling (1960). This series, supplemented by ice-core data processed as explained in Monroe (2014) for the pre-1958 period, shows continuously increasing levels of atmospheric $\mathrm{CO}_{2}$ from roughly the mid-nineteenth century. It provides a striking match to the instrumented record of the global mean surface temperature observations in Figure 1.

\section{IPCC Use of Heritage Data}

Among archaeologists there is a widespread and somewhat accurate perception that the IPCC ignores archaeological and historical data. For example, Ortman (see also Jackson et al. 2018) writes:

In recent years an increasing number of archaeologists have conducted research that is explicitly designed to address contemporary issues.... Despite many exciting results emanating from this work, as of yet it seems to have had little impact on actual public policy discussions. For example, despite extensive research by archaeologists on human responses to climate change, to date the results of such research have been largely absent from reports by the Intergovernmental Panel on Climate Change. . . . Given that the archaeological record is the most extensive compendium of human experience there is, it seems only natural that the results of archaeological research should have an impact on discussions concerning contemporary issues. . . . But so far there seems to have been limited success in this regard. Why is this? [Ortman 2019:1].

Rockman and Hritz (2020) explore some of the factors underlying this frustration. In the United States, for example, heritage is effectively invisible at the level of federal engagement with climate change. Lead responsibility for management of archaeology and other forms of cultural 
heritage lies with the U.S. National Park Service (NPS), but this responsibility is not recognized in its name, and the NPS prioritizes natural resources in its funding and staffing. The writing and structure of the U.S. National Climate Assessments have followed similar alignments. Rockman and Hritz (2020) argue that this has created a feedback loop such that as visible federal practice does not engage substantively with management or information aspects of archaeology and other forms of heritage with respect to climate change, it is acceptable and standard for subsequent reports and initiatives not to engage with archaeology or heritage either. Given these gaps, it becomes more difficult to demonstrate the utility of archaeology, because practitioners and scientists outside of archaeology have not substantively engaged with applications of archaeology to climate issues. When federal and nongovernmental organizations do address archaeology and heritage with respect to climate change, it is most often with direct reference to Indigenous communities (see, for example, the Global Commission on Adaptation 2019). Although impacts of climate change on Indigenous communities and contributions of traditional and Indigenous communities, knowledge, and practice to sustainable climate responses are critical and although attention to them should be expanded (see also Ford et al. 2016), such attention does not embrace all the potential contributions of archaeology to climate science and climate response.

Table 1 demonstrates that IPCC reports often do engage with heritage data that is broadly defined to include information gleaned from archaeological and historical investigation; ethnographies; and Indigenous, local, and traditional knowledge systems and practicesalthough their use of data that is specifically archaeological is indeed skimpier. We searched all the reports listed in Table 1 for their usage of a number of relevant terms (archaeol* archeol* prehist* tradition* 'cultural resources' indigen*). Below, we briefly summarize the contents of the useful hits by AR cycle and WG. Because subsequent reports often raise concerns already mentioned in previous reports, we emphasize those concerns and data usage that were novel in each report cycle.
It is obvious-for us at least-that when archaeologists focus on long-term social processes such as migration, population dynamics, human security, and health, we make contributions that are unobtainable by other social scientists working within the constraints of an instrumented climate record that is only a century or two in length in most areas. Below, however, we admit that archaeologists could do more to make our work on climate change relevant to the IPCC and to nonarchaeologists in general. One suggestion will be to seek to combine the vast number of cases embedded in the archaeological record to make statements about how societies tend to respond to climate variability that are more generalizable and impactful than individual studies by themselves. Another suggestion, based on work of the junior author in the federal government, is to engage archaeological research methods and cultural resources management practices to support conversations about values of place, identity, and story in the development of sustainable and just climate adaptation. Such integrative, comparative work is currently missing.

\section{First Assessment Report (FAR)}

The WGII report (Hashimoto et al. 1990:5-6) notes that climate change could produce large impacts on nomads and traditional societies, such as the Canadian Inuit and the Gwichin of Canada's Northwest Territories and Yukon Territory, by adversely affecting hunting, trapping, and fishing. It is also noted that nomadic inhabitants of the Sahara and the Arabian Peninsula could be adversely affected by warming. It also notes dangers to social and cultural resources due to flooding or sea-level change (Hashimoto et al. 1990:5-9). Climate change forcing migration may also cause psychological strains due to loss of connection with the original land and traditions (Hashimoto et al. 1990:5-10).

In the WGIII report, Gilbert and Vellinga note that retreat as an option in the face of sea-level rise could result in loss of "places of great cultural significance, for example, burial grounds, historic places, or religious centers" (1990:153).

In 1992, WGI and WGII published supplements to their 1990 reports. Tsyban and colleagues urged climate modelers to strengthen 
quantitative information in regional climate models by nesting them in coupled ocean-atmosphere global circulation models, in conjunction with a multidisciplinary effort examining the "historical, geological, and archaeological records" (1993:92).

\section{Second Assessment Report (SAR)}

The WGI report uses a range of archaeological and geological data to conclude that over the last century, average sea-level rise has accelerated relative to the average computed for the last two millennia (Warrick et al. 1996:366). Warrick and colleagues also note that the available archaeological sea-level data primarily reflect local tectonic land movement and that the Peltier post-glacial rebound models widely used by scientists studying climate change do not reproduce relative landsea movements that match those locally calculated using archaeological data (Warrick et al. 1996:390-391).

WGII authors project a number of effects from climate change in mountainous regions, including disruption of food and fuel for Indigenous populations in many developing countries (Watson et al. 1996:6). They recognize that forests in many parts of the world are not just of economic importance but also of spiritual importance to many Indigenous people. In Box 7-3, Fitzharris and colleagues (1996) project a number of deleterious changes to tundra lands that are likely to affect the Inuit of North America and Greenland as well as various reindeerherding groups of Eurasia, including diminution of ice and permafrost affecting size and load limit of vehicular traffic along with changes in migration patterns of polar bears and caribou. Bijlsma and colleagues note that Integrated Coastal Zone Management, "taking into account traditional, cultural, and historical perspectives and conflicting interests and uses" (Bijlsma et al. 1996:Box 9-5) should be employed to plan for sea-level rise accompanying warming. Levine and colleagues urge contemporary architects and urban planners to learn from the "energy-conscious design principles" (Levine et al. 1996:730) used in traditional building practices in tropical and Mediterranean countries.

\section{Third Assessment Report (TAR)}

WGI authors (Folland et al. 2001; Stocker et al. 2001) draw on archaeological data (Sandweiss et al. 1996) interpreted in conjunction with lake cores (Rodbell et al. 1999) as evidence for past variations in the strength and frequency of ENSO extremes.

The WGII report again notes dangers to coastal cultural resources under sea-level rise, using data from Fulford and colleagues (1997) and Pye and colleagues (2000) that were not available to SAR authors, and it considers the plight of Venice in particular (Kundzewicz et al. 2001). Mata and colleagues (2001) employ data from Meggers (1994) to suggest that climate change and human actions may lead to fires in Amazonia on the scale of the catastrophes that she reconstructed for $1500,1000,700$, and 400 BP, coincident with major El Niño events.

This same report includes the first hint that IPCC authors consider the archaeological record to potentially hold important lessons for how humans might adapt to climate change (Smit et al. 2001). They cite Rayner and Malone (1998) to the effect that the most promising research strategy is

explicitly to focus attention on the process of adaptation - or, on the other hand, of failure to adapt - that partly condition the impact of the climatic stress in particular societies . . . cases in which societies appear to have been seriously damaged by, or even totally succumbed to, climatic stress should not be taken to demonstrate the determining influence of climate. It is essential to consider ways in which these societies might have coped better, and to focus on the political, cultural, and socioeconomic factors which inhibited them from doing so (Ingram et al. 1981) [Smit et al. 2001:888].

They note that McGovern (1991) considered the climate stress connected with the extinction of the Greenland Norse to have been "theoretically" within the ability of the Norse to cope-although they did not. Consequently, in considering human adaptive response to climate change, it is important to consider how "adaptive capacity and hence vulnerability" modulate the effects 
of climate on society, including the possibility that different groups or members within a society may differ in their adaptive capacity (Smit et al. 2001:888).

This same chapter, however, exhibits a bit of inconsistency concerning the adaptive capacity of traditional societies in the face of climate change. The authors worry, on one hand, that acceptance of "western economic ideals" (Smit et al. 2001:898) and technologies may reduce this capacity by devaluing traditional ecological knowledge and cultural values (Newton 1995). On the other hand, they suggest that among the North American Inuit, vulnerability to climate change may have been reduced by "technological enhancement of adaptive capacity through the acquisition of snowmobiles, motorized boats, and even sonar" (Smit et al. 2001:898). In general, even though the prognosis for Indigenous peoples with respect to climate change is not always clear, beginning in TAR WGII, these communities receive much more attention than in the first two reports. Below, we emphasize the increasing IPCC use of archaeological and historical data rather than other forms of heritage data.

\section{AR4}

We follow IPCC usage in referring to this and subsequent reports in this new format (which avoids ambiguity for the abbreviation "FAR"). In the WGI report, archaeological and historical data are used solely in the paleoclimate chapter (Jansen et al. 2007). Well data from the last 2,000 years (Sivan et al. 2004), the timing and placement of Roman and Greek construction, and the placement of Roman fish ponds (Lambeck et al. 2004) are used to conclude that "the onset of the modern sea level rise occurred between 1850 and 1950" (Jansen et al. 2007:413).

This chapter also engages the Ruddiman hypothesis (Ruddiman 2003; Ruddiman et al. 2005) that an observed 20 ppm (parts per million) increase in atmospheric $\mathrm{CO}_{2}$ during the Holocene-which contrasts with a decrease of about that same amount during the three previous interglacials-was due to prehistoric agriculture, which released $\mathrm{CO}_{2}$ through the clearing of forests. They find this hypothesis untenable on a number of grounds, including orbital differences in these interglacials and the fact that some interglacials do have somewhat high $\mathrm{CO}_{2}$ levels (Jansen et al. 2007:460). Indirectly, of course, this points to the relevance of archaeological data on land use, population size, and subsistence practices to global climate histories in the Holocene.

In the WGII report, Anisimov and colleagues (2007) use archaeological data to demonstrate that human occupation of the Arctic stretches back at least 40,000 years ago (40 KYA; Pavlov et al. 2001) and to illustrate the importance of mobility for its past populations in adapting to resource uncertainty and climate change. Mobility options for current Arctic populations, by contrast, are increasingly curtailed by entanglements with the global economy that have entrained shifts in lifestyle and culture. Boko and colleagues make a similar point with respect to Africa, where "droughts have long contributed to human migration, cultural separation, population dislocation and the collapse of prehistoric and early historic societies" (2007:437, citing Pandey et al. 2003).

The Latin America chapter (Magrin et al. 2007) contains a box (13.2) entitled "Adaptation capacity of the South American highlands' preColombian communities" that highlights the numerous engineering and agricultural adaptations allowing these populations to deal with temporal and spatial mismatches between water supply and demand. These included engineering feats such as surface and underground irrigation channels, devices to measure the amount of water stored, and interconnections between drainages (Burger 1995; Caran and Neely 2006; Treacy 1994; Wright and Zegarra 2000) as well as an ability to forecast the El Niño cycles that so powerfully affect water supply in this region (Canziani and Mata 2004). The larger point is that these capacities could be usefully revisited and updated to provide local adaptations to current and future climate change.

\section{AR5 and Subsequent Special Reports}

AR5 is the most recent comprehensive assessment report currently available, published in 2013 and 2014. It engages archaeological information in more detail than did previous reports, 
although it is also longer in all respects. In the WGI volume, Ciais and colleagues, the authors of the chapter on carbon and other biogeochemical cycles, again wrestle with the effects of anthropogenic land use and land cover change (LULCC) on atmospheric $\mathrm{CO}_{2}$ from the early/ mid-Holocene (7 KYA) to the late Holocene (Ciais et al. 2014:Figure 6.5, lower panel). Measurements from air trapped in ice cores reveal that atmospheric concentrations of both $\mathrm{CO}_{2}$ and $\mathrm{CH}_{4}$ (methane) have been trending slowly upward, with some variability, for about the last 6 KYA (Ciais et al. 2014:Figure 6.6), with increases accelerating rapidly beginning around 1750 with the Industrial Revolution (Ciais et al. 2014:Figure 6.7). The authors note that global syntheses of the observational, paleoecological, and archaeological records are not yet available for the Holocene, and they have low confidence that LULCC reconstructions such as the HYDE model (Kaplan et al. 2011; Klein Goldewijk et al. 2011) accurately reflect regional differences in land-use systems and population densities over the mid- and late Holocene.

Ciais and colleagues consider the available information to indicate that "cumulative Holocene carbon emissions as a result of preindustrial LULCC were not large enough . . . to have had an influence larger than an increase of $\sim 10$ ppm [parts per million] on late Holocene observed $\mathrm{CO}_{2}$ concentration increase" (Ciais et al. 2014:484)_accounting for roughly half of the observed increase over the pre- 1850 period. They note, however, that one modeling study (Kaplan et al. 2011) suggested that the entire observed increase could have been released as a result of LULCC between 8000 $\mathrm{BP}$ and $\mathrm{AD} 1850$, because this team posits a much stronger loss of soil carbon in response to land-use change than do the other studies. It is clear that archaeologists could have an important role in narrowing these uncertainties, and in fact, some important spatialized estimates of paleodemography and subsistence regime crowdsourced from archaeologists relevant to LULCC have recently become available (Stephens et al. 2019).

The story for methane is somewhat similar. Post-Pleistocene atmospheric levels of $\mathrm{CH}_{4}$ reached a minimum of around $590 \mathrm{ppb}$ (parts per billion) near $5000 \mathrm{BP}$ and increased between then and AD 1750 by about $100 \mathrm{ppb}$ (Ciais et al. 2014:485). Ciais and colleagues (2014) note that Ruddiman (2007) and Fuller and colleagues (2011) have attributed this increase to domesticated ruminants after $5000 \mathrm{BP}$ and rice cultivation after 4000 BP. IPCC authors, however, consider the available models as supporting either a natural or an anthropogenic increase: "About as likely as not, the atmospheric $\mathrm{CH}_{4}$ increase after 5,000 years ago [up to the Industrial Revolution] can be attributed to early human activities" (Ciais et al. 2014:485; emphasis in original).

In AR5, the WGII report was divided into two volumes. Part A deals with global and sectoral (that is, a domain of interest, such as transportation or migration) issues. Part B deals with regional aspects. In Part A, several topics that received much greater emphasis in this report have archaeological and historical dimensions. In Chapter 12, Adger and colleagues (2014) assess archaeological and paleoclimatic data for their joint information on the relationship between climate change and human security, including conflict and social collapse. For example, they note evidence that the collapse of the Khmer Empire coincided with an unusually severe and prolonged drought (Buckley et al. 2010), mention the review by deMenocal (2001) that linked major changes in weather patterns with collapse of societies including the "Anasazi, the Akkadian, Classic Maya, Mochica, and Tiwanaku empires" (Adger et al. 2014:772), and cite a number of studies linking political upheaval in Europe, China, and the Ottoman Empire with the Little Ice Age. Overall, however, the tone struck in this chapter is judicious:

These studies all show that climate change can exacerbate major political changes given certain social conditions, including a predominance of subsistence producers, conflict over territory, and autocratic systems of government with limited power in peripheral regions. The precise causal pathways that link these changes in climate to changes in civilizations are not well understood due to data limitations. Therefore, it should be 
noted that these findings from historical antecedents are not directly transferable to the contemporary globalized world. The literature urges caution in concluding that mean future changes in climate will lead to large-scale political collapse (Butzer 2012) [Adger et al. 2014:772; emphasis added].

Chapter 16, which deals with adaptation opportunities, constraints, and limits (Klein et al. 2014), summarizes in Box 16-4 a great deal of archaeological and historical information about possible limits to adaptation visible in these data. Following some cautions to neither oversimplify cause and effect-in particular when matching climatic events with social crisesnor automatically consider that coincidence demonstrates causality, they state:

There are now roughly a dozen case studies of historical societies under stress, from different time ranges and several parts of the world, that are sufficiently detailed (based on field, archival, or other primary sources) for relevant analysis (Butzer and Endfield 2012). These include Medieval Greenland and Iceland (Dugmore et al. 2009; Streeter et al. 2012), Ancient Egypt (Butzer 2012), Colonial Cyprus (Harris 2012), the prehistoric Levant (Rosen and Rivera-Collazo 2012), Islamic Mesopotamia and Ethiopia (Butzer 2012), the Classic Maya (Dunning et al. 2012; Luzzadder-Beach et al. 2012), and Colonial Mexico (Endfield 2012). Seven such civilizations underwent drastic transformation in the wake of multiple inputs, triggers, and feedbacks, with unpredictable outcomes. These can be seen to have exceeded adaptation limits. Five other examples showed successful adaptation through the interplay of environmental, political, and socio-cultural resilience, which responded to multiple stressors (e.g., insecurity, environmental or crises, epidemics, famine). In these cases, climatic perturbations are identified as only one of many "triggers" of potential crisis, with preconditions necessary for such triggers to stimulate transformational change. These preconditions include human-induced environmental decline mainly through overexploitation [Klein et al. 2014:920].

In Part B of the WGII report-the regional chapters-archaeological sites and culturally valued buildings are noted to be at risk from sea-level rise and extreme events, with eventual results likely to include loss of heritage and declines in tourism (e.g., Kovats et al. 2014). The authors of the Small Islands chapter (Nurse et al. 2014) note disagreement as to whether past climate variability precipitated crises in prehistoric societies in much of the Pacific Basin, as argued by Nunn (2007). In contrast, Barnett (2001) has suggested that such past experiences have enabled island populations to develop resilient traits such as a belief in their own capacity and a familiarity with the range of conditions likely to be experienced.

Since AR5, the IPCC has produced three special reports (Table 1). Only one of these, The Ocean and Cryosphere in a Changing Climate (Pörtner et al. 2019), makes any substantial use of archaeological data. Glacial retreat with warming has been a source of spectacular finds such as Oetzi (Putzer and Festi 2014) as well as other discoveries in the Wrangell-Saint Elias Range (Dixon et al. 2005), the Rocky Mountains (Lee 2012), and Norway (Bjørgo et al. 2016). This is a mixed blessing, of course, because such materials also become newly exposed to harsh weather and degrade if they are not quickly recovered (Callanan 2016).

In this report we also see the first use of archaeological data as a source of information on previous densities, distributions, and histories of species of contemporary economic interest. Stable isotopes from archaeological cod bone are used to assert the stability of this resource over the last millennium in Norway and its probable future stability over the next 45 years, dependent on level of exploitation (Barrett et al. 2011; Eide 2017).

\section{Summary}

Over its three decades of existence, the work of the IPCC has become more inclusive of Indigenous knowledge and experience. More recently, it has begun to recognize the value of information from archaeology in fulfilling IPCC's mandate to 
understand both past and contemporary climate change and assess their likely social and economic impacts. Specifically, for the physical scientists of WGI, archaeological data have helped constrain past and current rates of sealevel rise and past variations in the strength and frequency of ENSO extremes. The extent of land-use cover and land-use change in the midand late Holocene has been examined to assess whether it was sufficient to have caused the slight contemporaneous increases observed in atmospheric greenhouse gases. Very recently, archaeofauna have been employed to help establish baseline distributions and population dynamics prior to industrial fishing for species of economic importance such as cod.

On the social science side, WGII authors have made some attempts to assess the extent to which past climatic variability can be connected to the fates of societies known mainly through archaeology. To a smaller extent, this has been coupled with an interest in why some societies appear to have been more resilient to climate change than others. In a few cases, specific adaptations developed in prehistory have been suggested as models for current and future populations. There has been a recognition that the vastly increased population levels in the contemporary world preclude the mobility that was clearly one of the main adaptations to climatic variability in prehistory. IPCC authors have been reluctant to draw direct lessons from the experience of ancient societies with relatively simple technology for contemporary globalized industrial society. Finally, IPCC authors have long recognized that archaeological and historical sites, and the information they contain on adaptation and on resource distributions, are themselves threatened by climate-driven impacts such as sea-level rise and glacial wastage.

\section{How Archaeology Can Have More Impact within the IPCC}

Advocates for more inclusion of Indigenous knowledge and experience in IPCC reports have noted that in the AR5 of WGII, only $2.9 \%$ of the authors had previously published on topics related to climate change and Indigenous peoples (Ford et al. 2012). Authorship expertise obviously affects both the structure and content of assessment reports-perhaps especially so in areas such as archaeology where the data are cumbersome, complicated, and difficult to deal with. And to be frank, our data surpass the patience of nonarchaeologists! That is why it is essential to have archaeologists on the IPCC writing teams. To date, as far as we can determine, there have been only two: Karl Butzer, who so capably strode across the fields of geography, ecology, and geoarchaeology, serving as a contributing author on Chapter 16 of the WGII report in AR5; and the senior author here, who is also a lead author of Chapter 14 (North America) in AR6, WGII. (Sociocultural anthropology has been better represented.) This leads to the first of our five main recommendations.

\section{Get Archaeologists on the IPCC Writing Teams}

The IPCC publishes a brochure called "How to participate in the IPCC" (IPCC 2020b) that provides guidelines for a variety of types of participation (reviewer, contributor to the primary literature, etc.), but of particular interest here is a fact sheet it references on author selection. We reviewed the usual routes to nomination as an author in the section titled "Purpose and Structure of the IPCC." Self-nominations are also possible by application to a governmental focal point (list available at https://www.ipcc. ch/apps/contact/interface/focalpoints.php). The process by which selection is made from the nominees is not very transparent, but there is an attempt to achieve an appropriate distribution of expertise, regions, developing and developed countries and countries with economies in transition, and younger and more senior researchers, all while also maintaining approximately equal numbers of men and women.

Although attention to these distributions is invaluable for many reasons, conversations of the junior author with several U.S. federal government staff involved in the IPCC nomination process noted the challenges they present for archaeological nominations. The United States, for example, has a high concentration of accomplished climate scientists, many of whom now have IPCC experience. When combined with IPCC preference for geographic and other diversity, this creates a high level of competition for 
nomination slots for nonclimate disciplines from the United States. Therefore, we recommend expanded coordination between archaeologists and archaeological societies to foster nominations of archaeological colleagues around the world.

\section{Bolster Archaeological Contributions to Paleoclimate Research}

Paleoclimates become relevant to IPCC concerns (especially for WGI) by providing quantitative information on the Earth system responses to external forcings (solar, volcanic, and orbital) and to changes in atmospheric composition (Masson-Delmotte et al. 2013) that are essential to calibrate climate models. Instrumental records cannot document Earth system feedbacks on time scales longer than two or three centuries, and they do not (yet) bear witness to transitions between different climate states.

The few examples from previous IPCC work reviewed above where archaeological data have been employed to help build or constrain paleoclimatic and paleoenvironmental reconstructions are a vast underestimate of the potential of such records. Archaeological sites are uniquely valuable repositories of coupled environmental and human (behavioral, cultural, demographic) information (Hambrecht et al. 2018). The profound impact of humans on the globe can really only be appreciated from the long time horizons archaeology provides. The poor health of twenty-first-century fisheries, for example, is starkly cast into relief by zooarchaeological data showing how "fishing down the food web" along the southeastern Atlantic coast of continental North America begins only in the late 1800s (Reitz 2014; St. Amand et al. 2020), following millennia during which this phenomenon was never observed. The power of the long time frame provided by archaeology is again demonstrated by $\mathrm{Xu}$ and colleagues (2020), who note that the geographical position of the favored human temperature niche is projected to move more in the next 50 years than it has in the last 6,000 .

Sandweiss and colleagues (2020) note that climate proxies that are unavailable or equivocal from more traditional sources have been developed from archaeological sites in coastal Peru.
Research by Weiss and colleagues (1993) at Tell Leilan on the Habur Plains of northern Mesopotamia (present-day Syria) identified a major aridification episode later verified in a marine core from the Gulf of Oman (Cullen et al. 2000). Weiss and a number of other archaeologists attribute the collapse of the Subir civilization in northern Mesopotamia, the disintegration of the Akkadian empire in southern Mesopotamia, and regional upheaval to this climatic episode (Sandweiss and Kelley 2012).

\section{Get More Archaeologists Working on the Effects of Climate Change on Society}

How people in the past, present, and future have dealt or may deal with climate change is central to WGII concerns. Adaptation is defined by the IPCC as "the process of adjustment to actual or expected climate and its effects. In human systems, adaptation seeks to moderate harm or exploit beneficial opportunities" (AR5 WGIII glossary, https://www.ipcc-data.org/guidelines/ pages/glossary/glossary_a.html).

Archaeologists will recognize this definition as similar to that favored by processualists such as Binford (1962), following White (1959). And yet, nearly all of us are also aware of the criticisms leveled at such thinking by other archaeologists beginning in the 1980s-namely, that such adaptive explanations have ties to a functional view of social systems that many now distrust. (It is clear, however, that functional explanations need not endorse a further functional view of social systems, although they do at least imply an evolutionary view of social systems that also came under attack at the same time [Preston 2014].) Adaptational concepts were also faulted for entailing a "radical occlusion of the individual" (Shanks and Tilley 1987:53), for their foregrounding of behaviors rather than the contextual meaning of social acts for the actors, and so forth (see Hodder 1986:18-33; Johnson 2010:68-88, 164-184).

Such criticisms have meant that since the 1980s, attempts to ascertain the extent to which societies have been influenced by climate change have often been characterized as "deterministic" in a distinctly reproachful sense (Arponen et al. 2019). To operate effectively in the IPCC world, however, archaeologists must minimally 
be open to the possibility that climate change can ramify through societies in multiple ways. Today, as we see charred remnants of what were rainforests in Australia just last year, as the world sets ever-higher temperature records almost annually, and as global food production systems begin to shift in response to changing climate regimes (Ray et al. 2019), this possibility seems all too plausible, and its denial verges on quaint.

We agree, however, with Arponen and colleagues that in archaeology, the dialogue has moved well beyond the stark oppositions of the 1980s. As they put it, archaeologists today struggle with "precisely where, along the continuum from external influence to internal societal dynamics, to locate the moving forces of prehistoric transformations" (Arponen et al. 2019:4). Being able to perform such determinations in a way that is maximally faithful to the facts of the record is essential to meeting the demands of working within the IPCC setting.

In addition, we recognize here that archaeology also has the capacity to support contemporary adaptation through conversations and actions enabled by archaeological connections to place, environment, and community. Potential for archaeology to provide such social support broadly has long been discussed, but practical demonstrations of methods and benefits in relation to climate change have only recently begun to develop. Examples include the ShoreDIGs and Learning from Loss projects managed by the SCAPE (Scottish Coastal Archaeology and the Problem of Erosion) Trust, which engages local communities not only in decisions about which elements of sites at risk of loss from erosion they most want to preserve and how but also in the preservation projects themselves (Dawson et al. 2020; SCAPE 2019). Citizen science for archaeological sites at risk from climate impacts is also underway in the United States by the Florida Public Archaeology Network (Miller and Murray 2018) and the Midden Minders project in Maine (Dawson et al. 2020). RiveraCollazo and colleagues have created the DUNAS (Descendants United for Nature, Adaptation, and Sustainability) project in Puerto Rico, which works with communities to restore coastal ecosystems damaged by Hurricane Maria with a focus on archaeological sites in dunes (Climate Science Alliance 2019). Archaeology is also part of the NPS "Every Place Has a Climate Story" project (Rockman and Maase 2017), which uses heritage and scientific narrative to help park staff connect visitors to climate change and place in a growing number of national parks. As these projects are all relatively new, their benefits for adaptation have not yet been assessed. As work on these projects and others continues to develop, we anticipate this area of connection between archaeology and adaptation also will be of interest to IPCC WGII.

\section{Pay More Attention to Formal Attribution for Sources of Change}

The IPCC has developed frameworks for "detection and attribution" that in turn permit a carefully calibrated set of terms reflecting degrees of confidence for claims of detection or attribution. The concept of detection is most easily applied and most commonly invoked to date by WGI. Can we clearly demonstrate that some aspect of climate has changed-for example, that a particular dimension is beyond the variability experienced in the recent past at some defined level of likelihood? The definition of "attribution"-a concept more aligned with WGII interests-is similarly straightforward: "Attribution is ... the process of evaluating the relative contributions of multiple causal factors to a change or event with an assignment of statistical confidence" (Agard and Schipper 2014:1763; emphasis added).

In practice, however, attribution becomes quite complex. The IPCC has issued a guidance note on both detection and attribution, which, although somewhat out of date, is still useful (Hegerl et al. 2010). Unfortunately, as a WGI product, none of its examples deals with attribution of change in human societies. Mach and colleagues (2017) evaluate use of expert judgment in characterizing uncertainty in AR5 and present a series of recommendations for future IPCC practice in this domain. It is clear that the sorts of verbal arguments that archaeologists often use to build cases for causal relationships are less likely to be assessed by IPCC readers as demonstrating causation with high confidence than are arguments that use formal statistical 
machinery whose probability of error can be read directly.

This is a critical point for archaeology: we cannot be taken seriously by other scientists if they do not judge our causal arguments to be credible. So, we want to take the time to sketch a taxonomy of typical approaches archaeologists use to build causal arguments (here, by way of example, to attribute variability in some aspect of society to variability in some possible climate driver). Assuming that the relationship in question has exactly the same strength of causal coupling for each of the scenarios we sketch, these examples provide a rough hierarchy of increasing confidence in the causation being asserted. The scenarios are motivated by the experience of the Village Ecodynamics Project (Kohler and Varien 2012), and especially its attempts to understand the relationship between climate and violence in the northern U.S. Southwest in periods when populations were heavily reliant on dry-farmed maize. We believe it will be generally portable to other explananda, times, and places. Your job as reader is to imagine that you are an IPCC author tasked with assigning a confidence level to the assertion that "climate variability that leads to low or highly variable crop production causes interpersonal or interpolity violence" in some specific region and span of years, based on the sorts of information presented in each scenario. So, there are three variables and two linkages between them: climate $\rightarrow$ agricultural production $\rightarrow$ violence, all of which require evaluation, minimally considering the concerns listed in Table 2. We add in brackets some legitimate doubts that you might have in each scenario.
Largely Verbal Arguments. Based on pollen, tree rings, or other proxies general to the Southwest, fairly long spans of time can be assessed as generally dry or unusually variable in precipitation. Sites in apparently defensive locations in some subareas of the Southwest seem to be more common in these periods, and a site with an apparent massacre was also in use in one of these periods. [A: Does the chosen climate proxy really apply to this area? B: How large is the effect of the climate variability on critical subsistence resources? C: How precise are the temporal placements of the proxies and their presumed effects? D: What is the distribution of site locations throughout all periods, and how is the "defensiveness" of locations determined? E: Would these relationships rise to statistical significance were they quantified, or could these apparent effects be due to chance alone? F: Are there other (possibly nonclimatic) considerations that could be responsible for the claimed effects?]

Simple Statistics Applied to More Credible Proxies. The situation is as above, except now the locations of all sites are quantified according to a measure of degree of defensibility (see, for example, Bocinsky [2014] for a possible quantification of locational defensibility on the Northwest coast). Sites and climatic proxies are characterized by periods of two centuries in length. A $\chi^{2}$ test shows that the relationship between periods assumed to be favorable/ unfavorable to maize production, and site counts in defensive/nondefensive locations, is unlikely to be due to chance. [This strengthens considerations D and E. But what about C? In periods of

Table 2. Dimensions of Concern in Trustworthiness of Attribution.

\begin{tabular}{|c|c|c|}
\hline Label & Dimension & Considerations \\
\hline A & Climate proxy & $\begin{array}{l}\text { Spatial applicability and resolution; reliability; level of } \\
\text { measurement }\end{array}$ \\
\hline B & $\begin{array}{l}\text { Coupling between climate proxy and production, } \\
\text { and between production and social effect }\end{array}$ & $\begin{array}{l}\text { Is the climate proxy demonstrably connected to subsistence } \\
\text { resources, and how tight is the coupling? Is the link between } \\
\text { subsistence production and other social effects convincing? }\end{array}$ \\
\hline $\mathrm{C}$ & Temporal precision & Of both the climate proxy and the presumed effects \\
\hline $\mathrm{D}$ & Social effect & Reliability of proxy; level of measurement \\
\hline $\mathrm{E}$ & Statistical significance and strength & How likely is chance as an explanatory factor? \\
\hline $\mathrm{F}$ & Alternative hypotheses & Are plausible alternative explanations for the effects examined? \\
\hline
\end{tabular}


this length, can we even be sure that the presumed cause precedes the stated effects?]

Simple Statistics with Still-Better Proxies, Higher Levels of Measurement, and Increased Temporal Precision. The situation is as above, but now the incidence of violence preserved on human remains is regressed on a trustworthy ratio-level model for maize production that is sensitive to annual temperature and precipitation variability, as well as spatial variability, and that draws on climate proxies that are local to the subarea with the sites. Violence is quantified by periods of 50 years on average. Regression shows that the relationships between low production, internally variable production, and incidence of violent trauma to human bone are unlikely to be due to chance. [Proxies are now more direct and credible, although there continues to be room for making distinctions among various types of violence (Martin 2016); level of measurement is higher; temporal precision (C) is improved; concerns A and B are now directly addressed. This describes the analysis in Kohler and colleagues (2014). But what about F? Are there confounding variables that need to be considered?]

Attempts to Control for Confounders and Incorporate Temporal Precedence into Statistical Models. Other work in this same portion of the Southwest has found that periods with high violence not only coincide with climatically induced production decreases but also immediately follow periods of high wealth inequality (Ellyson et al. 2019:Figure 6). Was violence perhaps more a reaction to unequal conditions of life than to poor production? (see Turchin [2013] for possible parallels in U.S. history). Now, we arrive at the limits of Village Ecodynamics Project analyses. Kohler and colleagues (2020) construct an informal causal network showing the synchronic and diachronic linkages among measures of inequality, violence, aggregation, population size, and average per capita maize production through time, leading them to (cautiously) conclude that variability in maize production was indeed more directly related to variability in violence than was variability in inequality. [One remaining problem with this causal chain is that there is no demonstration that the poor production of maize during periods of high violence would have been low enough to cause starvation or provoke raiding, so some details about the mechanism linking poor production to violence remain unspecified (B).]

Summary. Distilling the main elements here, causal arguments in archaeology will be more credible as we increase our temporal precision and sample sizes, the directness and credibility of our proxies on both the cause-and-effect sides of the chain and their level of measurement, our ability to demonstrate convincing mechanisms linking climatic variability and its purported effects, the power of our statistical approaches, and our ability to discount competing explanations or to weigh contributing factors appropriately.

This is a tall order for archaeology, but we should not give up hope. We are constantly seeing breakthroughs in chronology building from development of new techniques (Casanova et al. 2020) and better methods for pruning temporal uncertainty given multiple sources of chronological information (Colin et al. 2020). Agroecosystem models incorporating local climate signals are increasingly available in areas beyond the U.S. Southwest (e.g., Contreras et al. 2019). Archaeologists are once again turning their attention to problems of causation, which will be approachable only within the particular temporal coarse-graining allowed by various archaeological records (which must always be explicit). Climatic causation of social change will presumably always be partial; responses to climate change will reflect the specific internal social dynamics of societies in complex and multiscalar ways (Gronenborn et al. 2020; Hegmon et al. 2018; Naylor et al. 2020). Convincing models of causation from climate to society should examine the temporal dynamics of socio-natural systems in ways that also recognize the effects of societies on their ecosystems (Boivin et al. 2016) -for example, through agent-based models (e.g., Bocinsky et al. 2012). We need to become sophisticated in the use of tools such as Granger causality that honor the order and rate at which variables change through time (Zhang et al. 2011) and related recently developed methods for formal analysis of causal networks (Stavroglou et al. 2020); correlation is not enough (Contreras 2016). We are not very far along this path, 
but the direction of travel is fairly clear. It is true that a potent threat to our future is climate change that is largely anthropogenic, and what we can study in the past are the effects of climate change due to largely natural causes. This in itself, however, does not limit the power of the analogies we can draw (Currie 2018:293-308).

But these sophisticated demands are being asked of an archaeological record that itself is under threat from development and climate change.

\section{Increase Our Documentation of Loss and} Damage to Archaeological/Heritage Sites That Have Been or Will Soon Be Affected by Climate Change Impacts

We place this point last only because it seems so self-evident that detailed argument should not be needed. In 2016, as part of its Cultural Resources Climate Change Strategy (Rockman et al. 2016), the NPS released a compilation of observed and projected impacts of climate change on all major types of cultural heritage, including archaeology. Next stages of this work-such as when the impacts described are likely to occur and their geographic distribution-have not yet been developed. Anderson and colleagues (2017) have demonstrated that a $1 \mathrm{~m}$ rise in sea level will result in the loss of $>13,000$ recorded historic and prehistoric archaeological sites in just eight coastal states in the U.S. Southeast (for similar examples elsewhere in the world, see Dawson et al. 2020; Teruel Cano et al. 2020). An index developed by Williams and colleagues using tree-ring data, when projected into the future via climate models, suggests that by 2050, the mean forest drought stress in the U.S. Southwest will "exceed that of the most severe droughts in the past 1,000 years" (2013:1), with predictable results for forest productivity and mortality, bark-beetle outbreaks, wildfire, and the cultural heritage that forests contain. Permafrost thaw and coastal erosion endanger the information content and, often, the existence of countless archaeological and heritage sites in the Arctic (Hollesen et al. 2018).

Our professional ties to global heritage make it difficult to be dispassionate about how this heritage is affected by current and future climate change. As archaeologists, we must move quickly to document threatened sites. Yet, at the same time, we are required to weigh the evidence for climate change and its effects on past societies with professional detachment.

\section{Conclusions}

IPCC authors can find many reasons to discount archaeology's possible contributions to understanding current and future climate change. Our data are too coarse, too "gappy," they might say. Many of the cultures we study appear too distant in time and technology from the present. And even when instances of historical and industrial archaeology are brought to bear, the links between how archaeology approaches and understands the past and the specificity desired of science to inform contemporary policy are too weak.

Our purpose in this article is to provide a firmer basis for addressing such concerns and for strengthening the links between archaeology and climate science. And our effort here does not stand alone. As of the time of our writing, a coalition including the International Council on Monuments and Sites (ICOMOS); the United Nations Educational, Scientific and Cultural Organization (UNESCO); the International Union for Conservation of Nature (IUCN); and Local Governments for Sustainability (ICLEI) - and which is anticipated to also include the Facilitative Working Group of the UN Framework Convention on Climate Change (UNFCCC) Local Communities and Indigenous Peoples Platform - has just received approval from the IPCC of its proposal for an IPCC cosponsored Expert Meeting on culture, heritage, and climate change. This meeting will assess the status of knowledge of connections between culture, heritage-inclusive of archaeologyand climate change, and it will offer recommendations for how the IPCC may best develop and incorporate this knowledge.

Although we cannot say here what the format and outcomes of this meeting will be, what is clear from approval of the plan by the IPCC is that there is growing recognition that something has been missing from the global approach to climate change. Although climate change itself is recognized to be anthropogenic, 
the human systems, values, knowledge, and creativity necessary for effective, sustainable, and just solutions to climate change have not yet been fully engaged.

Consequently, we look to our archaeological colleagues to work with us to bring our field as fully into this process as possible. We should be asking questions such as, how large must the shortfall in available food be, relative to population, to precipitate social strife, emigration, or other responses? How large must the swell of climate migrants be relative to the indigenous population of an area to precipitate unrest? What factors of social structure most contribute to social resilience when tested against challenges that are similar in scale? We must demonstrate that there are strong patterns in the answers to such questions across many different types of societies-if indeed there are-through a program of long-term comparative research on archaeological societies of all scales. We should also seek out conversations with nonarchaeological climate colleagues in order to build further collaborations that hold meaning and relevance on both sides. The IPCC co-sponsored Expert Meeting will be one venue for such conversations. The five points raised above could be useful starting points for such discussions.

In arguing for an archaeology committed to studying climate change and its effects on society, we are of course not saying that the myriad other things we do are unimportant or should be discontinued. We build places of meaning where meanings have been forgotten (Hodder 2018). We enrich imaginations with strikingly alien pasts. We possibly provide wronged communities with resources for healing (Atalay 2019). Let us sustain those efforts while also encouraging rapid development of the comparative and predictive study of the effects of climate variability on societies of all types and scales. As the disciplinary custodians of the $98 \%$ of our species' history that is unwritten - and co-custodians of that which isthis is our responsibility.

Acknowledgments. Timothy Kohler thanks the Research Institute for Humanity and Nature in Kyoto, which hosted him as an Invited Scholar as he began work on this article, and Crow Canyon Archaeological Center, where he is a research associate. Three reviewers for American Antiquity —Dan Sandweiss and two anonymous ones-as well as editor Lynn Gamble provided very useful comments on our original draft. Outside of the review process, we are grateful for comments received from Jeff Hicke, Keith Kintigh, and Anne Pisor. Darcy Bird crafted Figure 1, and Isabel RiveraCollazo translated the abstract. Marcy Rockman thanks Hana Morel from the Institute of Archaeology, University College London, who provided a foundation and inspiration for analysis of heritage terms in IPCC reports, and ICOMOS and UNESCO colleagues for their collaboration in preparing the IPCC cosponsorship proposal. Our experiences working in or on the fringes of large-scale projects and collaborations such as the DAP, VEP, NABO, and LTVTP have undoubtedly influenced many of our opinions, and we thank their conveners and members.

Data Availability Statement. No original data are presented in this article.

\section{References Cited}

Adger, W. Neil, Juan M. Pulhin, Jon Barnett, Geoffrey D. Dabelko, Grete K. Hovelsrud, Marc Levy, Úrsula Oswald Spring, and Coleen H. Vogel

2014 Human Security. In Climate Change 2014: Impacts, Adaptation, and Vulnerability. Part A: Global and Sectoral Aspects. Contribution of Working Group II to the Fifth Assessment Report of the Intergovernmental Panel on Climate Change, edited by Christopher B. Field, Vicente R. Barros, David J. Dokken, Katharine J. Mach, Michael D. Mastrandrea, T. Eren Bilir, Monalisa Chatterjee, Kristie L. Ebi, Yuka O. Estrada, Robert C. Genova, Betelhem Girma, Eric S. Kissel, Andrew N. Levy, Sandy MacCracken, Patricia R. Mastrandrea, and Leslie L. White, pp. 755-791. Cambridge University Press, Cambridge.

Agard, John, and E. Lisa F. Schipper

2014 Annex II: Glossary. In Climate Change 2014 Impacts, Adaptation, and Vulnerability Part B: Regional Aspects, edited by Vicente R. Barros, Christopher B. Field, David J. Dokken, Michael D. Mastrandrea, Katharine J. Mach, T. Eren Bilir, Monalisa Chatterjee, Kristie L. Ebi, Yuka O. Estrada, Robert C. Genova, Betelhem Girma, Eric S. Kissel, Andrew N. Levy, Sandy MacCracken, Patricia R. Mastrandrea, and Leslie L. White, pp. 1757-1776. Cambridge University Press, Cambridge.

Anderson, David G., Thaddeus G. Bissett, Stephen J. Yerka, Joshua J. Wells, Eric C. Kansa, Sarah W. Kansa, Kelsey Noack Myers, R. Carl DeMuth, and Devin A. White

2017 Sea-Level Rise and Archaeological Site Destruction: An Example from the Southeastern United States Using DINAA (Digital Index of North American Archaeology). PLoS ONE 12(11):e0188142. DOI:10.1371/ journal.pone.0188142.

Anisimov, Oleg A., David G. Vaughan, Terry V. Callaghan, Christopher Furgal, Harvey Marchant, Terry D. Prowse, Hjalmar Vilhjálmsson, and John E. Walsh

2007 Polar Regions (Arctic and Antarctic). In Climate Change 2007: Impacts, Adaptation and Vulnerability, edited by Martin L. Parry, Osvaldo F. Canziani, Jean P. Palutikof, Paul J. van der Linden, and Clair E. Hanson, pp. 653-685. Cambridge University Press, Cambridge. 
Arponen, V. P. J., Walter Dörfler, Ingo Feeser, Sonja Grimm, Daniel Groß, Martin Hinz, Daniel Knitter, Nils Müller-Scheeßel, Konrad Ott, and Artur Ribeiro

2019 Environmental Determinism and Archaeology. Understanding and Evaluating Determinism in Research Design. Archaeological Dialogues 26:1-9. DOI:10. 1017/S1380203819000059.

Arrhenius, Svante

1896 On the Influence of Carbonic Acid in the Air upon the Temperature of the Ground. The London, Edinburgh, and Dublin Philosophical Magazine and Journal of Science 41:237-276. DOI:10.1080/14786449608620846.

1908 Worlds in the Making: The Evolution of the Universe. Translated by $\mathrm{H}$. Borns. Harper \& Brothers, New York.

Atalay, Sonya

2019 Braiding Strands of Wellness: How Repatriation Contributes to Healing through Embodied Practice and Storywork. Public Historian 41:78-89.

Barnett, Jon

2001 Adapting to Climate Change in Pacific Island Countries: The Problem of Uncertainty. World Development 29:977-993. DOI:10.1016/S0305-750X(01)00022-5.

Barnett, Harold J., and Chandler Morse

1963 Scarcity and Growth: The Economics of Natural Resource Availability. Resources for the Future and Johns Hopkins University Press, Baltimore, Maryland.

Barrett, James H., David Orton, Cluny Johnstone, Jennifer Harland, Wim Van Neer, Anton Ervynck, Callum Roberts, Alison Locker, Colin Amundsen, Inge Bødker Enghoff, Sheila Hamilton-Dyer, Dirk Heinrich, Anne Karin Hufthammer, Andrew K. G. Jones, Leif Jonsson, Daniel Makowiecki, Peter Pope, Tamsin C. O'Connell, Tessa de Roo, and Michael Richards

2011 Interpreting the Expansion of Sea Fishing in Medieval Europe Using Stable Isotope Analysis of Archaeological Cod Bones. Journal of Archaeological Science 38:1516-1524. DOI:10.1016/j.jas.2011.02.017.

Bijlsma, Luitzen, C. N. Ehler, R. J. T. Klein, S. M. Kulshrestha, R. F. McLean, N. Mimura, R. J. Nicholls, L. A. Nurse, H. Pérez Nieto, E. Z. Stakhiv, R. K. Turner, and R. A. Warrick

1996 Coastal Zones and Small Islands. In Climate Change 1995: Impacts, Adaptations and Mitigation of Climate Change: Scientific-Technical Analyses, edited by Robert T. Watson, Marufu C. Zinyowera, and Richard H. Moss, pp. 289-324. Cambridge University Press, Cambridge.

Binford, Lewis R.

1962 Archaeology as Anthropology. American Antiquity 28:217-225.

Bjørgo, Tore, Trond Linge, Øystein Skår, Solveig Lohne Rongved, and Tore Slinning

2016 Fragments of a Late Iron Age Sledge Melted out of the Vossaskavlen Snowdrift Glacier in Western Norway. Journal of Glacial Archaeology 2:73-81. DOI:10.1558/ jga.v2i1.27719.

Bocinsky, R. Kyle

2014 Extrinsic Site Defensibility and Landscape-Based Archaeological Inference: An Example from the Northwest Coast. Journal of Anthropological Archaeology 35:164-176.

Bocinsky, R. Kyle, Jason A. Cowan, Timothy A. Kohler, and C. David Johnson

2012 How Hunting Changes the VEP World, and How the
VEP World Changes Hunting. In Emergence and Collapse of Early Villages: Models of Central Mesa Verde Archaeology, edited by Timothy A. Kohler and Mark D. Varien, pp. 145-152. University of California Press, Berkeley.

Boivin, Nicole L., Melinda A. Zeder, Dorian Q. Fuller, Alison Crowther, Greger Larson, Jon M. Erlandson, Tim Denham, and Michael D. Petraglia

2016 Ecological Consequences of Human Niche Construction: Examining Long-Term Anthropogenic Shaping of Global Species Distributions. Proceedings of the National Academy of Sciences of the United States of America 113:6388-6396.

Boko, Michael, Isabelle Niang, Anthony Nyong, Coleen Vogel, Andrew Githeko, Mahmoud Medany, Balgis Osman-Elasha, Ramadjita Tabo, and Pius Z. Yanda

2007 Africa. In Climate Change 2007: Impacts, Adaptation, and Vulnerability. Contribution of Working Group II to the Fourth Assessment Report of the Intergovernmental Panel on Climate Change, edited by Martin L. Parry, Osvaldo F. Canziani, Jean P. Palutikof, Paul J. van der Linden, and Clair E. Hanson, pp. 433-467. Cambridge University Press, Cambridge.

Buckley, Brendan M., Kevin J. Anchukaitis, Daniel Penny, Roland Fletcher, Edward R. Cook, Masaki Sano, Le Canh Nam, Aroonrut Wichienkeeo, Ton That Minh, and Truong M. Hong

2010 Climate as a Contributing Factor in the Demise of Angkor, Cambodia. Proceedings of the National Academy of Sciences of the United States of America 107:6748-6752. DOI:10.1073/pnas.0910827107.

Burger, Richard L.

1995 Chavin and the Origins of Andean Civilization. Thames and Hudson, London.

Butzer, Karl W.

2012 Collapse, Environment, and Society. Proceedings of the National Academy of Sciences of the United States of America 109:3632-3639. DOI:10.1073/pnas.1114845109.

Butzer, Karl W., and Georgina H. Endfield

2012 Critical Perspectives on Historical Collapse. Proceedings of the National Academy of Sciences of the United States of America 109:3628-3631. DOI:10. 1073/pnas.1114772109.

Callanan, Martin

2016 Managing Frozen Heritage: Some Challenges and Responses. Quaternary International 402:72-79. DOI:10.1016/j.quaint.2015.10.067.

Canziani, Osvaldo F., and Luis J. Mata

2004 The Fate of Indigenous Communities under Climate Change. Paper presented at the UNFCCC Workshop on Impacts of, and Vulnerability and Adaptation to, Climate Change. Tenth Session of the Conference of Parties (COP-10), Buenos Aires.

Caran, S. Christopher, and James A. Neely

2006 Hydraulic Engineering in Prehistoric Mexico. Scientific American 295(4):78-85. DOI:10.1038/scientific american1006-78.

Carson, Rachel

1962 Silent Spring. Houghton Mifflin, Boston.

Casanova, Emmanuelle, Timothy D. J. Knowles, Alex Bayliss, Julie Dunne, Marek Z. Barański, Anthony Denaire, Philippe Lefranc, Savino di Lernia, Mélanie RoffetSalque, Jessica Smyth, Alistair Barclay, Toby Gillard, Erich Claßen, Bryony Coles, Michael Ilett, Christian Jeunesse, Marta Krueger, Arkadiusz Marciniak, Steve 
Minnitt, Rocco Rotunno, Pieter van de Velde, Ivo van Wijk, Jonathan Cotton, Andy Daykin, and Richard P. Evershed

2020 Accurate Compound-Specific ${ }^{14} \mathrm{C}$ Dating of Archaeological Pottery Vessels. Nature 580:1-5. DOI:10.1038/ s41586-020-2178-z.

Ciais, Philippe, Christopher Sabine, Govindasamy Bala, Laurent Bopp, Victor Brovkin, Josep Canadell, Abha Chhabra, Ruth DeFries, James Galloway, Martin Heimann, Christopher Jones, Corinne Le Quéré, Ranga B. Myneni, Shilong Piao, and Peter Thornton

2014 Carbon and Other Biogeochemical Cycles. In Climate Change 2013: The Physical Science Basis. Contribution of Working Group I to the Fifth Assessment Report of the Intergovernmental Panel on Climate Change, edited by Thomas F. Stocker, Dahe Qin, Gian-Kasper Plattner, Melinda Tignor, Simon K. Allen, Judith Boschung, Alexander Nauels, Yu Xia, Vincent Bex, and Pauline M. Midgley, pp. 465-570. Cambridge University Press, Cambridge.

Climate Science Alliance

2019 DUNAS: Descendants United for Nature, Adaptation, and Sustainability. Electronic document, https:// www.climatesciencealliance.org/dunas, accessed June 14,2020

Colin, Frédéric, Anita Quiles, Mathieu Schuster, Dominique Schwartz, Catherine Duvette, Sylvie Marchand, Mennat-Allah El Dorry, and Johan van Heesch

2020 The End of the "Green Oasis": Chronological Bayesian Modeling of Human and Environmental Dynamics in the Bahariya Area (Egyptian Sahara) from Pharaonic Third Intermediate Period to Medieval Times. Radiocarbon 62:25-49. DOI:10.1017/RDC. 2019.106

Contreras, Daniel A.

2016 Correlation Is Not Enough: Building Better Arguments in the Archaeology of Human-Environment Interactions. In The Archaeology of Human-Environment Interactions, edited by Daniel A. Contreras, pp. 17-36. Routledge, Abingdon, United Kingdom.

Contreras, Daniel A., Alberte Bondeau, Joel Guiot, Alan Kirman, Eneko Hiriart, Loup Bernard, Romain Suarez, and Marianela Fader

2019 From Paleoclimate Variables to Prehistoric Agriculture: Using a Process-Based Agro-Ecosystem model to Simulate the Impacts of Holocene Climate Change on Potential Agricultural Productivity in Provence, France. Quaternary International 501:303-316.

Cullen Heidi M., Peter B. deMenocal, S. Hemming, G. Hemming, F. H. Brown, T. Guilderson, and F. Sirocko

2000 Climate Change and the Collapse of the Akkadian Empire: Evidence from the Deep Sea. Geology 28:379-382.

Currie, Adrian

2018 Rock, Bone, and Ruin: An Optimist's Guide to the Historical Sciences. MIT Press, Cambridge, Massachusetts.

Dawson, Tom, Joanna Hambly, Alice Kelley, William Lees, and Sarah Miller

2020 Coastal Heritage, Global Climate Change, Public Engagement, and Citizen Science. Proceedings of the National Academy of Sciences of the United States of America 117:8280-8286.

deMenocal, Peter B.

2001 Cultural Responses to Climate Change during the
Late Holocene. Science 292:667-673. DOI:10.1126/ science. 1059287.

De Steiguer, Joseph Edward

2006 The Origins of Modern Environmental Thought. University of Arizona Press, Tucson.

Dixon, James E., William F. Manley, and Craig M. Lee

2005 The Emerging Archaeology of Glaciers and Ice Patches: Examples from Alaska's Wrangell-St. Elias National Park and Preserve. American Antiquity 70:129-143. DOI:10.2307/40035272.

Dugmore, Andrew J., Christian Keller, Thomas H. McGovern, Andrew F. Casely, and Konrad Smiarowski

2009 Norse Greenland Settlement and Limits to Adaptation. In Adapting to Climate Change: Thresholds, Values, Governance, edited by W. Neil Adger, Irene Lorenzoni, and Karen L. O'Brien, pp. 96-113. Cambridge University Press, Cambridge.

Dunning, Nicholas P., Timothy P. Beach, and Sheryl Luzzadder-Beach

2012 Kax and Kol: Collapse and Resilience in Lowland Maya Civilization. Proceedings of the National Academy of Sciences of the United States of America 109:3652-3657. DOI:10.1073/pnas.1114838109.

Earth Day Network

2020 The History of Earth Day. Electronic document, https://www.earthday.org/history/, accessed May 1, 2020.

Eide, Arne

2017 Climate Change, Fisheries Management, and Fishing Aptitude Affecting Spatial and Temporal Distributions of the Barents Sea Cod Fishery. Ambio 46(Suppl 3):387399. DOI:10.1007/s13280-017-0955-1.

Ellyson, Laura J., Timothy A. Kohler, and Catherine M. Cameron

2019 How Far from Chaco to Orayvi? Quantifying Inequality among Pueblo Households. Journal of Anthropological Archaeology 55:101073. DOI:10. 1016/j.jaa.2019.101073.

Endfield, Georgina $\mathrm{H}$.

2012 The Resilience and Adaptive Capacity of Social-Environmental Systems in Colonial Mexico. Proceedings of the National Academy of Sciences of the United States of America 109:3676-3681. DOI:10. 1073/pnas.1114831109.

Fitzharris, B. Blair, I. Allison, R. J. Braithwaite, J. Brown, P. M. B. Foehn, W. Haeberli, K. Higuchi, V. M. Kotlyakov, T. D. Prowse, C. A. Rinaldi, P. Wadhams, M.-K. Woo, Xie Youyu, O. Anisimov, A. Aristarain, R. A. Assel, R. G. Barry, R.D. Brown, F. Dramis, S. Hastenrath, A. G. Lewkowicz, E. C. Malagnino, S. Neale, F. E. Nelson, D. A. Robinson, P. Skvarca, A. E. Taylor, and A. Weidick

1996 The Cryosphere: Changes and Their Impacts. In Climate Change 1995: Impacts, Adaptations, and Mitigation of Climate Change: Scientific-Technical Analyses, edited by Robert T. Watson, Marufu C. Zinyowera, and Richard H. Moss, pp. 241-265. Cambridge University Press, Cambridge.

Folland, C. K., T. R. Karl, J. R. Christy, R. A. Clarke, G. V. Gruza, J. Jouzel, M. E. Mann, J. Oerlemans, M. J. Salinger, and S. W. Wang

2001 Observed Climate Variability and Change. In Climate Change 2001: The Scientific Basis, edited by John T. Houghton, Ding Yihui, D. J. Griggs, M. Noguer, P. J. van der Linden, and X. Dai, pp. 99-182. Cambridge University Press, Cambridge. 
Ford, James D., Laura Cameron, Jennifer Rubis, Michelle Maillet, Douglas Nakashima, Ashlee Cunsolo Willox, and Tristan Pearce

2016 Including Indigenous Knowledge and Experience in IPCC Assessment Reports. Nature Climate Change 6:349-353.

Ford, James D., Will Vanderbilt, and Lea Berrang-Ford

2012 Authorship in IPCC AR5 and Its Implications for Content: Climate Change and Indigenous Populations in WGII. Climatic Change 113:201-213. DOI:10. 1007/s10584-011-0350-z.

Fulford, Michael, Timothy Champion, and Antony Long

1997 England's Coastal Heritage: A Survey for English Heritage and the RCHME. Archaeological Report 15. Royal Commission on the Historical Monuments of England and English Nature, Swindon, England.

Fuller, Dorian Q., Jacob van Etten, Katie Manning, Cristina Castillo, Eleanor Kingwell-Banham, Alison Weisskopf, Ling Qin, Yo-Ichiro Sato, and Robert J. Hijmans

2011 The Contribution of Rice Agriculture and Livestock Pastoralism to Prehistoric Methane levels: An Archaeological Assessment. Holocene 21:743-759. DOI:10. 1177/0959683611398052.

Gilbert, J. T. E., and P. Vellinga

1990 Coastal Zone Management. In Climate Change: The IPCC Response Strategies, edited by Frederick Bernthal, E. Dowdeswell, J. Luo, D. Attard, and P. Vellinga, pp. 129-160. Intergovernmental Panel on Climate Change. Island Press, Washington, DC.

Global Commission on Adaptation

2019 Adapt Now: A Global Call for Leadership on Climate Resilience. World Resources Institute, Washington, DC.

Gronenborn, Detlef, Hans-Christoph Strien, Kai Wirtz, Peter Turchin, Christoph Zielhofer, and Rolf van Dick

2020 Inherent Catastrophes? Social Dynamics and External Forcing in Early Neolithic and Modern SW Germany. In Going Forward by Looking Back: Archaeological Perspectives on Socio-Ecological Crisis, Response, and Collapse, edited by Felix Reide and Payson Sheets, pp. 333-366. Berghahn, New York.

Hambrecht, George, Cecilia Anderung, Seth Brewington, Andrew Dugmore, Ragnar Edvardsson, Francis Feeley, Kevin Gibbons, Ramona Harrison, Megan Hicks, Rowan Jackson, Guðbjörg Ásta Ólafsdóttir, Marcy Rockman, Konrad Smiarowski, Richard Streeter, Vicki Szabo, and Thomas McGovern

2018 Archaeological Sites as Distributed Long-Term Observing Networks of the Past (DONOP). Quaternary International, in press. DOI:10.1016/j.quaint.2018.04. 016.

Harris, Sarah E.

2012 Cyprus as a Degraded Landscape or Resilient Environment in the Wake of Colonial Intrusion. Proceedings of the National Academy of Sciences of the United States of America 109:3670-3675. DOI:10.1073/pnas. 1114085109

Hashimoto, M., M. Styrikovich, S. Nishioka, C. Rouviere. T. Williams, R. Ball, Y. Shinyak, J. Topping, S. Nishioka, M. Ando, and T. Okita

1990 Human Settlement; the Energy, Transport and Industrial Sectors; Human Health; Air Quality; and Changes in Ultraviolet-B Radiation. In Climate Change: The IPCC Impacts Assessment, edited by W. J. McG. Tegart, G. W. Sheldon, and D. C. Griffiths, pp. 5-1-
5-45. Australian Government Publishing Service, Canberra.

Hegerl, Gabriele C., Ove Hoegh-Guldberg, Gino Casassa, Martin P. Hoerling, Sari Kovats, Camille Parmesan, David W. Pierce, and Peter A. Stott

2010 Good Practice Guidance Paper on Detection and Attribution Related to Anthropogenic Climate Change. In Meeting Report of the Intergovernmental Panel on Climate Change Expert Meeting on Detection and Attribution of Anthropogenic Climate Change, edited by Thomas Stocker, Christopher Field, Qin Dahe, Vicente Barros, Gian-Kasper Plattner, Melinda Tignor, Pauline Midgley, and Kristie Ebi, pp. 1-8. IPCC Working Group I Technical Support Unit, University of Bern, Bern, Switzerland.

Hegmon, Michelle, and Matthew A. Peeples, and LTVTPNABO

2018 The Human Experience of Social Transformation: Insights from Comparative Archaeology. PLoS ONE 13(11):e0208060. DOI:10.1371/journal.pone.0208060.

Hodder, Ian

1986 Reading the Past: Current Approaches to Interpretation in Archaeology. Cambridge University Press, Cambridge.

2018 Big History and a Post-Truth Archaeology? SAA Archaeological Record 18(5):43-45. Electronic document, http://onlinedigeditions.com/publication/? $\mathrm{m}=16146 \& \mathrm{i}=542220 \& \mathrm{p}=44$, accessed June 1, 2020.

Hollesen, Jørgen, Martin Callanan, Tom Dawson, Rasmus Fenger-Nielsen, T. Max Friesen, Anne M. Jensen, Adam Markham, Vibeke V. Martens, Vladimir V. Pitulko, and Marcy Rockman

2018 Climate Change and the Deteriorating Archaeological and Environmental Archives of the Arctic. Antiquity 92:573-586. DOI:10.15184/aqy.2018.8.

Ingram, M. J., G. Farmer, and T. M. L. Wigley

1981 Past Climates and their Impacts on Man: A Review. In Climate and History: Studies in Past Climates and their Impact on Man, edited by T. M. L. Wigley, M. J. Ingram, and G. Farmer, pp. 3-50. Cambridge University IPCC Press, Cambridge.

2013 Appendix A to the Principles Governing IPCC Work. Procedures for the Preparation, Review, Acceptance, Adoption, Approval and Publication of IPCC Reports. Electronic document, https://www.ipcc.ch/ site/assets/uploads/2018/09/ipcc-principles-appendixa-final.pdf, accessed May 1, 2020.

2018 List of IPCC Observers Organizations (152 as of 16 March 2018). Electronic document, https://www.ipcc. ch/site/assets/uploads/2018/11/IPCC-observers.pdf, accessed June 1, 2020.

2020a Factsheet: What Is the IPCC? Electronic document, https://archive.ipcc.ch/news_and_events/docs/factsheets/ FS_what_ipcc.pdf, accessed May 1, 2020.

$2020 \mathrm{~b}$ How to Participate in the IPCC. Electronic document, https://www.ipcc.ch/site/assets/uploads/2019/09/ Participate_IPCC_en.pdf, accessed July 5, 2020.

Jackson, Rowan C., Andrew J. Dugmore, and Felix Riede

2018 Rediscovering Lessons of Adaptation from the Past. Global Environmental Change: Human and Policy Dimensions 52:58-65. DOI:10.1016/j.gloenvcha.2018. 05.006.

Jansen, Eystein, Jonathan Overpeck, Keith R. Briffa, JeanClaude Duplessy, Fortunat Joos, Valérie Masson-Delmotte, Daniel Olago, Bette Otto-Bliesner, W. Richard Peltier, 
Stefan Rahmstorf, Rengaswamy Ramesh, Dominique Raynaud, David Rind, Olga Solomina, Ricardo Villalba, and De'er Zhang

2007 Palaeoclimate. In Climate Change 2007: The Physical Science Basis, edited by Susan Solomon, Dahe Qin, Martin Manning, Zhenlin Chen, Melinda Marquis, Kristen B. Averyt, Melinda Tignor, and Henry L. Miller, pp. 435497. Cambridge University Press, Cambridge.

Johnson, Matthew

2010 Archaeological Theory: An Introduction. 2nd ed. Wiley-Blackwell, Chichester, UK.

Kaplan, Jed O., Kristen M. Krumhardt, Erle C. Ellis, William F. Ruddiman, Carsten Lemmen, and Kees Klein Goldewijk

2011 Holocene Carbon Emissions as a Result of Anthropogenic Land Cover Change. Holocene 21:775-791. DOI:10.1177/0959683610386983.

Keeling, Charles D.

1960 The Concentration and Isotopic Abundances of Carbon Dioxide in the Atmosphere. Tellus 12:200-203. DOI:10.1111/j.2153-3490.1960.tb01300.x.

Klein, Richard J. T., Guy F. Midgley, Benjamin L. Preston, Mozaharul Alam, Frans G. H. Berkhout, Kirstin Dow, and M. Rebecca Shaw

2014 Adaptation Opportunities, Constraints, and Limits. In Climate Change 2014: Impacts, Adaptation, and Vulnerability. Part A: Global and Sectoral Aspects. Contribution of Working Group II to the Fifth Assessment Report of the Intergovernmental Panel on Climate Change, edited by Christopher B. Field, Vicente R. Barros, David J. Dokken, Katharine J. Mach, Michael D. Mastrandrea, T. Eren Bilir, Monalisa Chatterjee, Kristie L. Ebi, Yuka O. Estrada, Robert C. Genova, Betelhem Girma, Eric S. Kissel, Andrew N. Levy, Sandy MacCracken, Patricia R. Mastrandrea, and Leslie L. White, pp. 899-943. Cambridge University Press, Cambridge.

Klein Goldewijk, Kees, Arthur Beusen, Gerard Van Drecht, and Martine De Vos

2011 The HYDE 3.1 Spatially Explicit Database of Human-Induced Global Land-Use Change over the Past 12,000 Years. Global Ecology and Biogeography 20:73-86.

Kohler, Timothy A., Laura J. Ellyson, and R. Kyle Bocinsky

2020 Beyond One-Shot Hypotheses: Explaining Three Increasingly Large Collapses in the Northern Pueblo Southwest. In Going Forward by Looking Back: Archaeological Perspectives on Socio-Ecological Crisis, Response, and Collapse, edited by Felix Reide and Payson Sheets, pp. 304-332. Berghahn, New York.

Kohler, Timothy A., Katie Grundtisch, Scott G. Ortman, Carly Fitzpatrick, and Sarah M. Cole

2014 The Better Angels of Their Nature: Declining Conflict through Time among Prehispanic Farmers of the Pueblo Southwest. American Antiquity 79:444-464.

Kohler, Timothy A., and Mark D. Varien

2012 Emergence and Collapse of Early Villages in the Central Mesa Verde. In Emergence and Collapse of Early Villages: Models of Central Mesa Verde Archaeology, edited by Timothy A. Kohler and Mark D. Varien, pp. 1-14. University of California Press, Berkeley.

Kovats, R. Sari, Riccardo Valentini, Laurens M. Bouwer, Elena Georgopoulou, Daniela Jacob, Eric Martin, Mark Rounsevell, and Jean-Francois Soussana
2014 Europe. In Climate Change 2014: Impacts, Adaptation, and Vulnerability. Part B: Regional Aspects. Contribution of Working Group II to the Fifth Assessment Report of the Intergovernmental Panel on Climate Change, edited by Vicente R. Barros, Christopher B. Field, David J. Dokken, Michael D. Mastrandrea, Katharine J. Mach, T. Eren Bilir, Monalisa Chatterjee, Kristie L. Ebi, Yuka O. Estrada, Robert C. Genova, Betelhem Girma, Eric S. Kissel, Andrew N. Levy, Sandy MacCracken, Patricia R. Mastrandrea, and Leslie L. White, pp. 1267-1326. Cambridge University Press, Cambridge.

Kundzewicz, Zbigniew W., Martin L. Parry, W. Cramer, J. I. Holten, Z. Kaczmarek, and P. W. Martens

2001 Europe. In Climate Change 2001: Impacts, Adaptation, and Vulnerability, edited by James J. McCarthy, Osvaldo F. Canziani, Neil A. Leary, David J. Dokken, and Kasey S. White, pp. 641-692. Cambridge University Press, Cambridge.

Lambeck, Kurt, Marco Anzidei, Fabrizio Antonioli, Alessandra Benini, and Alessandra Esposito

2004 Sea Level in Roman Time in the Central Mediterranean and Implications for Recent Change. Earth and Planetary Science Letters 224:563-575. DOI:10.1016/ j.epsl.2004.05.031.

Lee, Craig $\mathrm{M}$.

2012 Withering Snow and Ice in the Mid-Latitudes: A New Archaeological and Paleobiological Record for the Rocky Mountain Region. Arctic 65:165-177.

Leopold, Aldo

1949 A Sand County Almanac and Sketches Here and There. Oxford University Press, New York.

Levine, Mark D., H. Akbari, J. Busch, G. Dutt, K. Hogan, P. Komor, S. Meyers, H. Tsuchiya, G. Henderson, L. Price, K. R. Smith, and L. Siwei

1996 Mitigation Options for Human Settlements. In Climate Change 1995: Impacts, Adaptations, and Mitigation of Climate Change: Scientific Technical Analyses, edited by Robert T. Watson, Marufu C. Zinyowera, and Richard H. Moss, pp. 713-744. Cambridge University Press, Cambridge.

Luzzadder-Beach, Sheryl, Timothy P. Beach, and Nicholas P. Dunning

2012 Wetland Fields as Mirrors of Drought and the Maya Abandonment. Proceedings of the National Academy of Sciences of the United States of America 109:36463651. DOI:10.1073/pnas.1114919109.

Mach, Katharine J., Michael D. Mastrandrea, Patrick T. Freeman, and Christopher B. Field

2017 Unleashing Expert Judgment in Assessment. Global Environmental Change 44:1-14. DOI:10.1016/j. gloenvcha.2017.02.005.

Magrin, Graciela, Carlos Gay García, David Cruz Choque, Juan Carlos Giménez, Ana Rosa Moreno, Gustavo J. Nagy, Carlos Nobre, and Alicia Villamizar

2007 Latin America. In Climate Change 2007: Impacts, Adaptation, and Vulnerability. Contribution of Working Group II to the Fourth Assessment Report of the Intergovernmental Panel on Climate Change, edited by Martin L. Parry, Osvaldo F. Canziani, Jean P. Palutikof, Paul J. van der Linden, and Clair E. Hanson, pp. 581-615. Cambridge University Press, Cambridge.

Marsh, George Perkins

1864 Man and Nature: Or, Physical Geography as Modified by Human Action. Charles Scribner, New York. 
Martin, Debra L.

2016 Hard Times in Dry Lands: Making Meaning of Violence in the Ancient Southwest. Journal of Anthropological Research 72:1-23.

Masson-Delmotte, Valérie, Michael Schulz, Ayako AbeOuchi, Jürg Beer, Andrey Ganopolski, Jesus Fidel González Rouco, Eystein Jansen, Kurt Lambeck, Jürg Luterbacher, Tim Naish, Timothy Osborn, Bette Otto-Bliesner, Terrence Quinn, Rengaswamy Ramesh, Maisa Rojas, XueMei Shao, and Axel Timmermann

2013 Information from Paleoclimate Archives. In Climate Change 2013: The Physical Science Basis. Contribution of Working Group I to the Fifth Assessment Report of the Intergovernmental Panel on Climate Change, edited by Thomas F. Stocker, Dahe Qin, Gian-Kasper Plattner, Melinda Tignor, Simon K. Allen, Judith Boschung, Alexander Nauels, Yu Xia, Vincent Bex, and Pauline M. Midgley, pp. 383-464. Cambridge University Press, Cambridge.

Mata, Luis Jose, Max Campos, E. Basso, R. Compagnucci, P. Fearnside, G. Magrin, J. Marengo, A. R. Moreno, A. Suárez, S. Solman, and A. Villamizar

2001 Latin America. In Climate Change 2001: Impacts, Adaptation, and Vulnerability, edited by James J. McCarthy, Osvaldo F. Canziani, Neil A. Leary, David J. Dokken, and Kasey S. White, pp. 693-734. Cambridge University Press, Cambridge.

McGovern, Thomas H.

1991 Climate, Correlation, and Causation in Norse Greenland. Arctic Anthropology 28(2):77-100.

Meggers, Betty J.

1994 Archeological Evidence for the Impact of MegaNino Events on Amazonia during the Past Two Millennia. Climatic Change 28:321-338.

Miller, Sarah E., and Emily Jane Murray

2018 Heritage Monitoring Scouts: Engaging the Public to Monitor Sites at Risk across Florida. Conservation and Management of Archaeological Sites 20:234-260.

Monroe, Rob

2014 How are Ice-Core Data and Mauna Loa Atmospheric Data Made Comparable? The Keeling Curve, March 20, 2014. Electronic document, https://scripps.ucsd.edu/ programs/keelingcurve/2014/03/20/how-are-ice-core-dataand-mauna-loa-atmospheric-data-made-comparable/,

NASA accessed April 15, 2020.

2020 World of Change: Global Temperatures. NASA Earth Observatory. Electronic document, https://earth observatory.nasa.gov/world-of-change/global-tempera tures, accessed April 15, 2020.

NASA GISS [Goddard Institute for Space Studies]

2020 Data. GISS: GISS Surface Temperature Analysis (v4): Analysis Graphs and Plots. National Aeronautics and Space Administration, Goddard Institute for Space Studies. Electronic document, https://data.giss. nasa.gov/gistemp/graphs_v4/, accessed February 3, 2020.

Nash, Roderick Frazier

1967 Wilderness and the American Mind. Yale University Press, New Haven, Connecticut.

Naylor, Angus, James Ford, Tristan Pearce, and James Van Alstin

2020 Conceptualizing Climate Vulnerability in Complex Adaptive Systems. One Earth 2(5):444-454. DOI:10. 1016/j.oneear.2020.04.011.
Newton, John

1995 An Assessment of Coping with Environmental Hazards in Northern Aboriginal Communities. The Canadian Geographer / Le Geographe canadien 39:112-120. DOI:10.1111/j.1541-0064.1995.tb00406. $\mathrm{x}$.

Nunn, Patrick D.

2007 Climate, Environment, and Society in the Pacific during the Last Millennium. Developments in Earth and Environmental Sciences Vol. 6. Elsevier, Amsterdam.

Nurse, Leonard A., Roger F. McLean, John Agard, Lino Briguglio, Virginie Duvat-Magnan, Netatua Pelesikoti, Emma Tompkins, and Arthur Webb

2014 Small Islands. In Climate Change 2014: Impacts, Adaptation, and Vulnerability. Part B: Regional Aspects. Contribution of Working Group II to the Fifth Assessment Report of the Intergovernmental Panel on Climate Change, edited by Christopher B. Field, Vicente R. Barros, David J. Dokken, Katharine J. Mach, Michael D. Mastrandrea, T. Eren Bilir, Monalisa Chatterjee, Kristie L. Ebi, Yuka O. Estrada, Robert C. Genova, Betelhem Girma, Eric S. Kissel, Andrew N. Levy, Sandy MacCracken, Patricia R. Mastrandrea, and Leslie L. White, pp. 1613-1654. Cambridge University Press, Cambridge.

Ortman, Scott G.

2019 A New Kind of Relevance for Archaeology. Frontiers in Digital Humanities 6. DOI:10.3389/fdigh. 2019.00016

Pandey, Deep Narayan, Anil K. Gupta, and David M. Anderson

2003 Rainwater Harvesting as an Adaptation to Climate Change. Current Science 85:46-59.

Pavlov, Pavel, John I. Svendsen, and Svein Indrelid

2001 Human Presence in the European Arctic Nearly 40,000 Years Ago. Nature 413:64-67. DOI:10.1038/ 35092552 .

Pörtner, Hans-Otto, Debra C. Roberts, Valérie MassonDelmotte, Panmao Zhai, Melinda Tignor, Elvira Poloczanska, Katja Mintenbeck, Andrés Alegría, Maike Nicolai, Andrew Okem, Jan Petzold, Bardhyl Rama, and Nora M. Weyer (editors)

2019 IPCC Special Report on the Ocean and Cryosphere in a Changing Climate. Intergovernmental Panel on Climate Change, Geneva, Switzerland.

Preston, John

2014 Positivist and Post-Positivist Philosophy of Science. The Oxford Handbook of Archaeological Theory, edited by Andrew Gardner, Mark Lake, and Ulrike Sommer. Oxford University Press, Oxford. DOI:10.1093/ oxfordhb/9780199567942.013.031.

Putzer, Andreas, and Daniela Festi

2014 Nicht nur Ötzi? - Neufunde aus dem Tisental (Gem. Schnals/Prov. Bozen). Praehistorische Zeitschrift 89:55-71.

Pye, Kenneth, John R. L. Allen, and Geological Society of London

2000 Coastal and Estuarine Environments: Sedimentology, Geomorphology, and Geoarchaeology. Geological Society Special Publication No. 175. Geological Society of London, London.

Ray, Deepak K., Paul C. West, Michael Clark, James S. Gerber, Alexander V. Prishchepov, and Snigdhansu Chatterjee

2019 Climate Change Has Likely Already Affected 
Global Food Production. PLoS ONE 14(5):e0217148. DOI:10.1371/journal.pone.0217148.

Rayner, Steve, and Elizabeth L. Malone

1998 Ten Suggestions for Policymakers: Guidelines from an International Social Science Assessment of Human Choice and Climate Change. In Human Choice and Climate Change, edited by Elizabeth L. Malone and Steve Rayner, pp. 109-138. Batelle Press, Columbus, Ohio.

Reitz, Elizabeth J.

2014 Continuity and Resilience in the Central Georgia Bight (USA) Fishery between 2760 BC and AD 1580. Journal of Archaeological Science 41:716-731.

Rockman, Marcy, and Carrie Hritz

2020 Expanding Use of Archaeology in Climate Change Response by Changing Its Social Environment. Proceedings of the National Academy of Sciences of the United States of America 117:8295-8305.

Rockman, Marcy, and Jakob Maase

2017 Every Place Has a Climate Story: Finding and Sharing Climate Stories with Cultural Heritage. In Public Archaeology and Climate Change, edited by Tom Dawson, Courtney Nimura, Elías Lopez-Romero,, and Marie-Yvane Daire, pp. 107-114. Oxbow Books, Oxford.

Rockman, Marcy, Marissa Morgan, Sonya Ziaja, George Hambrecht, and Alison Meadow

2016 Cultural Resources Climate Change Strategy. Cultural Resources, Partnerships, and Science and Climate Change Response Program, National Park Service, Washington, DC.

Rodbell, Donald T., Geoffrey O. Seltzer, David M. Anderson, Mark B. Abbott, David B. Enfield, and Jeremy H. Newman

1999 An 15,000-Year Record of El Niño-Driven Alluviation in Southwestern Ecuador. Science 283:516 520. DOI:10.1126/science.283.5401.516.

Rosen, Arlene M., and Isabel Rivera-Collazo

2012 Climate Change, Adaptive Cycles, and the Persistence of Foraging Economies during the Late Pleistocene/Holocene Transition in the Levant. Proceedings of the National Academy of Sciences of the United States of America 109:3640-3645. DOI:10.1073/pnas. 1113931109

Ruddiman, William F.

2003 Orbital Iinsolation, Ice volume, and Greenhouse Gases. Quaternary Science Reviews 22:1597-1629. DOI:10.1016/S0277-3791(03)00087-8.

2007 The Early Anthropogenic Hypothesis: Challenges and Responses. Reviews of Geophysics 45(4). DOI:10. 1029/2006RG000207.

Ruddiman, William F., Stephen J. Vavrus, and John E. Kutzbach

2005 A Test of the Overdue-Glaciation Hypothesis. Quaternary Science Reviews 24:1-10. DOI:10.1016/j.quas cirev.2004.07.010.

Sandweiss, Daniel H., C. Fred, T. Andrus, Alice R. Kelley, Kirk A. Maasch, Elizabeth J. Reitz, and Paul B. Roscoe

2020 Archaeological Climate Proxies and the Complexities of Reconstructing Holocene El Niño in Coastal Peru. Proceedings of the National Academy of Sciences of the United States of America 117:82718279.

Sandweiss, Daniel H., and Alice R. Kelley

2012 Archaeological Contributions to Climate Change Research: The Archaeological Record as a Paleoclimatic and Paleoenvironmental Archive. Annual Reviews in Anthropology 41:371-391.

Sandweiss, Daniel H., James B. Richardson, Elizabeth J. Reitz, Harold B. Rollins, and Kirk A. Maasch

1996 Geoarchaeological Evidence from Peru for a 5000 Years B.P. Onset of El Niño. Science 273:1531-1533. DOI:10.1126/science.273.5281.1531.

\section{SCAPE}

2019 Learning from Loss: Reflections on Eroding Coastal Archaeology. YouTube, February 6, 11:33. https://www. youtube.com/watch? $\mathrm{v}=\mathrm{d} 56 \mathrm{y} 7 \mathrm{UxiE} 3 \mathrm{~A}$, accessed June 14, 2020.

Shanks, Michael, and Christopher Y. Tilley

1987 Social Theory and Archaeology. Polity Press, Cambridge.

Sivan, Dorit, Kurt Lambeck, R. Toueg, Avner Raban, Yosef Porath, and Boris Shirman

2004 Ancient Coastal Wells of Caesarea Maritima, Israel, an Indicator for Relative Sea Level Changes during the Last 2000 Years. Earth and Planetary Science Letters 222:315-330. DOI:10.1016/j.eps1.2004.02.007.

Smit, Barry, Olga Pilifosova, I. Burton, B. Challenger, S. Huq, R. J. T. Klein, and G. Yohe

2001 Adaptation to Climate Change in the Context of Sustainable Development and Equity. In Climate Change 2001: Impacts, Adaptation, and Vulnerability, edited by James J. McCarthy, Osvaldo F. Canziani, Neil A. Leary, David J. Dokken, and Kasey S. White, pp. 877-912. Cambridge University Press, Cambridge.

St. Amand, Frankie, S. Terry Childs, Elizabeth J. Reitz, Sky Heller, Bonnie Newsom, Torben C. Rick, Daniel H. Sandweiss, and Ryan Wheeler

2020 Leveraging Legacy Archaeological Collections as Proxies for Climate and Environmental Research. Proceedings of the National Academy of Sciences of the United States of America 117:8287-8294.

Stavroglou, Stavros K., Athanasios A. Pantelous, H. Eugene Stanley, and Konstantin M. Zuev

2020 Unveiling Causal Interactions in Complex Systems. Proceedings of the National Academy of Sciences of the United States of America 117:7599-7605. DOI:10. 1073/pnas.1918269117.

Stephens, Lucas, Dorian Fuller, Nicole Boivin, Torben Rick, Nicolas Gauthier, Andrea Kay, Ben Marwick, Chelsey Geralda Armstrong, C. Michael Barton, Tim Denham, Kristina Douglass, Jonathan Driver, Lisa Janz, Patrick Roberts, J. Daniel Rogers, Heather Thakar, Mark Altaweel, Amber L. Johnson, Maria Marta Sampietro Vattuone, Mark Aldenderfer, Sonia Archila, Gilberto Artioli, Martin T. Bale, Timothy Beach, Ferran Borrell, Todd Braje, Philip I. Buckland, Nayeli Guadalupe Jiménez Cano, José M. Capriles, Agustín Diez Castillo, Çiler Çilingiroğlu, Michelle Negus Cleary, James Conolly, Peter R. Coutros, R. Alan Covey, Mauro Cremaschi, Alison Crowther, Lindsay Der, Savino di Lernia, John F. Doershuk, William E. Doolittle, Kevin J. Edwards, Jon M. Erlandson, Damian Evans, Andrew Fairbairn, Patrick Faulkner, Gary Feinman, Ricardo Fernandes, Scott M. Fitzpatrick, Ralph Fyfe, Elena Garcea, Steve Goldstein, Reed Charles Goodman, Jade Dalpoim Guedes, Jason Herrmann, Peter Hiscock, Peter Hommel, K. Ann Horsburgh, Carrie Hritz, John W. Ives, Aripekka Junno, Jennifer G. Kahn, Brett Kaufman, Catherine Kearns, Tristram R. Kidder, François Lanoë, Dan Lawrence, Gyoung-Ah Lee, Maureece J. Levin, Henrik B. 
Lindskoug, José Antonio López-Sáez, Scott Macrae, Rob Marchant, John M. Marston, Sarah McClure, Mark D. McCoy, Alicia Ventresca Miller, Michael Morrison, Giedre Motuzaite Matuzeviciute, Johannes Müller, Ayushi Nayak, Sofwan Noerwidi, Tanya M. Peres, Christian E. Peterson, Lucas Proctor, Asa R. Randall, Steve Renette, Gwen Robbins Schug, Krysta Ryzewski, Rakesh Saini, Vivian Scheinsohn, Peter Schmidt, Pauline Sebillaud, Oula Seitsonen, Ian A. Simpson, Arkadiusz Sołtysiak, Robert J. Speakman, Robert N. Spengler, Martina L. Steffen, Michael J. Storozum, Keir M. Strickland, Jessica Thompson, T. L. Thurston, Sean Ulm, M. Cemre Ustunkaya, Martin H. Welker, Catherine West, Patrick Ryan Williams, David K. Wright, Nathan Wright, Muhammad Zahir, Andrea Zerboni, Ella Beaudoin, Santiago Munevar Garcia, Jeremy Powell, Alexa Thornton, Jed O. Kaplan, MarieJosé Gaillard, Kees Klein Goldewijk, and Erle Ellis

2019 Archaeological Assessment Reveals Earth's Early Transformation through Land Use. Science 365:897902. DOI:10.1126/science.aax1192.

Stocker, Thomas F., G. K. C. Clarke, H. Le Treut, R. S. Lindzen, V. P. Meleshko, R. K. Mugara, T. N. Palmer, R. T. Pierrehumbert, P. J. Sellers, K. E. Trenberth, and J. Willebrand

2001 Physical Climate Processes and Feedbacks. In Climate Change 2001: The Scientific Basis, edited by John T. Houghton, Ding Yihui, D. J. Griggs, M. Noguer, P. J. van der Linden, X. Dai, K. Maskell, and C. A. Johnson, pp. 417-470. Cambridge University Press, Cambridge.

Stocker, Thomas F., Dahe Qin, Gian-Kasper Plattner, Melindaa Tignor, Simon K. Allen, Judith Boschung, Alexander Nauels, Yu Xia, Vincent Bex, and Pauline M. Midgley (editors)

2013 Climate Change 2013: The Physical Science Basis. Intergovernmental Panel on Climate Change, Working Group I Contribution to the IPCC Fifth Assessment Report (AR5).

Streeter, Richard, Andrew J. Dugmore, and Orri Vésteinsson 2012 Plague and Landscape Resilience in Premodern Iceland. Proceedings of the National Academy of Sciences of the United States of America 109:3664-3669. DOI:10.1073/pnas.1113937109.

GISTEMP Team

2020 GISS Surface Temperature Analysis (GISTEMP), version 4. Electronic document, https://data.giss.nasa. gov/gistemp/, accessed January 30, 2020.

Teruel Cano, D., Sandra Fatorić, and Martijn Manders

2020 The Impact of Climate Change on Cultural Heritage in the Netherlands: A Preliminary Assessment of Exposure. Delft University of Technology, Delft, Netherlands. Electronic document, https://doi.org/10.4233/ uuid:73f6506d-c07e-481a-8f43-735a5ea87a43, accessed June 1, 2020.

Treacy, John M.

1994 Las chacras de Coporaque: Andenería y riego en el valle del Colca. Vol. 12. Instituto de Estudios Peruanos, Lima, Peru.

Trigger, Bruce

1971 Archaeology and Ecology. World Archaeology 2:321-336. DOI:10.1080/00438243.1971.9979483.

Tsyban, A., J. T. Everett, and M. Perdomo

1993 World Oceans and Coastal Zones: Ecological Effects. In Climate Change 1992: The Supplementary Report to the IPCC Impacts Assessment, edited by
W. J. McG. Tegart and G. W. Sheldon, pp. 86-93. Australian Government Publishing Service, Canberra.

Turchin, Peter

2013 Return of the Oppressed. Aeon, July 7. Electronic document, https://aeon.co/essays/history-tells-us-wherethe-wealth-gap-leads, accessed June 1, 2020.

Udall, Stewart L.

1963 The Quiet Crisis. Rinehart and Winston, New York.

United Nations General Assembly

1988 Document A/RES/43/53 Electronic document, https://documents-dds-ny.un.org/doc/RESOLUTION/ GEN/NR0/530/32/IMG/NR053032.pdf?OpenElement, accessed July 22, 2020.

Warrick, R. A., C. Le Provost, M. F. Meier, J. Oerlemans, and P. L. Woodworth

1996 Change in Sea Level. In Climate Change 1995: The Science of Climate Change. Contribution of Working Group I to the Second Assessment Report of the Intergovernmental Panel on Climate Change, edited by J. T. Houghton, L. G. Meira Filho, B. A. Callander, N. Harris, A. Kattenberg and K. Maskell, pp. 359-406. Cambridge University Press, Cambridge.

Watson, Patty Jo

2008 Processualism and After. In Handbook of Archaeological Theories, edited by R. Alexander Bentley, Herbert D. G. Maschner, and Christopher Chippindale, pp. 29-38. AltaMira, Lanham, Maryland.

Watson, Robert T., Marufu C. Zinyowera, and Richard H. Moss (editors)

1996 Climate Change 1995: Impacts, Adaptations, and Mitigation of Climate Change: Scientific-Technical Analyses: Contribution of Working Group II to the Second Assessment Report of the Intergovernmental Panel on Climate Change. Cambridge University Press, Cambridge.

Weiss, Harvey, M.-A, Courty, W. Wetterstrom, F. Guichard, L. Senior, R. Meadow, and A. Curnow

1993 The Genesis and Collapse of Third Millennium North Mesopotamian Civilization. Science 261:9951004.

White, Leslie A.

1959 The Evolution of Culture: The Development of Civilization to the Fall of Rome. McGraw-Hill, New York.

Williams, A. Park, Craig D. Allen, Alison K. Macalady, Daniel Griffin, Connie A. Woodhouse, David M. Meko, Thomas W. Swetnam, Sara A. Rauscher, Richard Seager, Henri D. Grissino-Mayer, Jeffrey S. Dean, Edward R. Cook, Chandana Gangodagamage, Michael Cai, and Nate G. McDowell

2013 Temperature as a Potent Driver of Regional Forest Drought Stress and Tree Mortality. Nature Climate Change 3:292-297.

Wright, Kenneth R., and Alfredo Valencia Zegarra

2000 Machu Picchu: A Civil Engineering Marvel. ASCE Press, Reston, Virginia.

$\mathrm{Xu}$, Chi, Timothy A. Kohler, Timothy M. Lenton, JensChristian Svenning, and Marten Scheffer

2020 Future of the Human Climate Niche. Proceedings of the National Academy of Sciences of the United States of America 117:11350-11355. DOI:10.1073/pnas. 1910114117.

Zelinka, Mark D., Timothy A. Myers, Daniel T. McCoy, Stephen Po-Chedley, Peter M. Caldwell, Paulo Ceppi, Stephen A. Klein, and Karl E. Taylor

2020 Causes of Higher Climate Sensitivity in CMIP6 
Models. Geophysical Research Letters 47. DOI:10. 1029/2019GL085782.

Zhang, David D., Harry F. Lee, Cong Wang, Baosheng Li, Qing Pei, Jane Zhang, and Yulun An

2011 The Causality Analysis of Climate Change and Large-Scale Human Crisis. Proceedings of the National
Academy of Sciences of the United States of America 108:17296-17301. DOI:10.1073/pnas.1104268108.

Submitted April 15, 2020; Revised June 17, 2020; Accepted June 19, 2020 